\title{
Development and Biomechanical Investigation of a New Compound Palatal Arch
}

\section{Entwicklung und biomechanische Untersuchung eines neuen Compound-Palatinalbogens}

\author{
Andrea Wichelhaus', Christian Sander², Franz Günter Sander ${ }^{2}$
}

\begin{abstract}
Background and Aim: There are many advantages in using a transpalatal arch in orthodontic treatment. In addition to the active movement of individual teeth, such an arch can be used to provide additional anchorage. The aim of this study was to further develop and improve both the clinical and the biomechanical properties of the conventional transpalatal arch.

Material and Methods: Currently available compound material components form an established part of orthodontic therapy. The Compound palatal $\operatorname{arch}^{\circledR}$ broadens the scope of this treatment system. The biomechanical effects of the newly developed Compound palatal $\operatorname{arch}^{\circledR}$ were verified by comparing them with those of commercially available conventional transpalatal arches. The recently developed Compound palatal $\operatorname{arch}^{\circledR}$ is made of one compound element: nickel-titanium/stainless steel. The specific dimensions and design of the nickel-titanium element are aimed at exploiting its superelasticity, even during active molar movement. The biomechanical investigation was carried out using sixcomponent measuring sensors to register the forces and moments in the three spatial dimensions $(\mathrm{x}, \mathrm{y}$ and $\mathrm{z})$ at $37^{\circ} \mathrm{C}$. The following appliances were investigated: Goshgarian transpalatal arch, quad-helix appliance, Arndt memory expander ${ }^{\circledR}$, and Compound palatal $\operatorname{arch}^{\circledR}$.

Results: Transpalatal arches could not be inserted without the arch being under tension. This is particularly important when the arch is being used for anchorage purposes. The Goshgarian arch had to be classified as problematic for the movement of single teeth as the load/deflection rate was high. However, this can be utilized for anchorage purposes. The clinical advantage of a quad-helix appliance is the option for asymmetric tooth movement.

Conclusions: This study showed that the quad-helix was effective for both unilateral and bilateral derotation as well as for transversal tooth movement. However, expansions should be
\end{abstract}

\footnotetext{
'Department of Orthodontics and Pediatric Dentistry, University of Basel, Switzerland,

${ }^{2}$ Department of Orthodontics, University of UIm, Germany.
}

Recieved: March 15, 2002; accepted: November 3, 2003

\section{Zusammenfassung}

Hintergrund und Ziel: In der Anwendung von Transpalatinalbögen ergeben sich viele Vorteile in der orthodontischen Therapie. Neben der aktiven Bewegung von Einzelzähnen werden Palatinalbögen ebenfalls als Verankerungselemente verwendet. Ziel dieser Studie war die Weiterentwicklung und Verbesserung konventioneller Transpalatinalbögen sowohl klinisch als auch biomechanisch.

Material und Methode: Bereits entwickelte Compound-Behandlungselemente sind etablierte Behandlungsmaterialien in der orthodontischen Therapie. Der Compound-Palatinalbogen ${ }^{\circledR}$ erweitert dieses Behandlungssystem. Zur Verifizierung der biomechanischen Effekte wurde der neu entwickelte Compound-Palatinalbogen ${ }^{\circledR}$ mit konventionellen, auf dem Markt befindlichen Palatinalbögen verglichen. Der neu entwickelte Compound-Palatinalbogen ${ }^{\circledR}$ besteht aus einem Compound-Element: NiTi-Stahl. Durch die spezifische Größe und den Einbau des NiTi-Elementes soll die Superelastizität auch bei aktiven Zahnbewegungen am Molaren nutzbar gemacht werden. Die biomechanische Untersuchung erfolgte mit Sechs-Komponenten-Messsensoren zur Darstellung der Kräfte und Momente in drei Ebenen des Raumes ( $x$, $y, z)$ bei $37^{\circ} \mathrm{C}$. Folgende Bögen wurden untersucht: Goshgarian, Quadhelix, Arndt-Memory-Expander ${ }^{\circledR}$, Compound-Palatinalbogen ${ }^{\circledR}$.

Ergebnisse: Es zeigte sich, dass ein spannungsfreies Einsetzen von Palatinalbögen nicht möglich ist - insbesondere bei Anwendung von Transpalatinalbögen in der Verankerung ein klinisch zu beachtender Effekt. Der Goshgarian-Bogen war für die Bewegung von Einzelzähnen als problematisch einzustufen, da die Last-/ Biegerate groß war. Dies kann jedoch in der Verankerung genutzt werden. Der Vorteil von Quadhelices liegt klinisch in der Lösung von asymmetrischen Zahnbewegungen.

Schlussfolgerungen: Diese Studie zeigt, dass sich Quadhelices gut für die ein-/beidseitige Derotation und Transversalbewegung eignen. Es sollte jedoch nicht mehr als $4 \mathrm{~mm}$ expandiert und

J Orofac Orthop 2004;65:104-22

DOI 10.1007/s00056-004-0214-5 
confined to $\leq 4 \mathrm{~mm}$, and derotations to $<10^{\circ}$, as forces and moments are otherwise not within the physiologic range. The Arndt memory expander ${ }^{\circledR}$ displayed no advantages over either the quad-helix appliance or the Goshgarian transpalatal arch. Nor did it display any superelastic properties. The linear relationship, the relatively high forces and moments, and the lack of clinical adjustability cast doubts on the benefits of this appliance. The newly developed Compound palatal $\operatorname{arch}^{\circledR}$ showed substantial advantages in molar derotation compared with conventional transpalatal arches. Superelastic properties were achieved through the design and positioning of the nickel-titanium element. Expansion with the Compound palatal $\operatorname{arch}^{\circledR}$ was comparable with that with conventional transpalatal arches. The clinical advantage is in the fact that this appliance can be reactivated and that dental asymmetries can be treated.

Key Words: Palatal arch · Quad-helix · Nickel-titanium • Goshgarian transpalatal arch · Arndt memory ex-

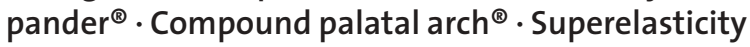

\section{Introduction}

The use of lingual and transpalatal arches in routine orthodontic practice can be regarded as widespread. Transpalatal arches are used on the one hand for the three-dimensional adjustment of molars, and on the other - though in combination with other elements such as implants or acrylic plates in the palate region - to provide anchorage for other teeth. Three-dimensional molar movement implies transversal change, derotation, torquing or combinations of these. According to Angle [2], Andrews [1], McNamara \& Brudon [23], Ricketts [26], Staller [33], and Strang [34], the position of the molars is an important factor in good treatment. In most cases, according to Proffit [25], it is an incorrect position of the molars that makes it impossible to establish correct occlusion.

Transpalatal and lingual arches have to meet different, indication-dependent requirements. Single tooth movement requires a system applying defined forces and moments to the respective tooth. Materials with a lower E-modulus are suitable for such applications. Conventional transpalatal arches such as the Goshgarian arch or the quad-helix appliance are made of steel materials with a correspondingly high E-modulus. Because of the linear behavior of the material, activation is to be seen as problematic as minor deviations in activation may produce unphysiologically high forces and moments. More userfriendly are materials giving the clinician a greater scope for activation. TMA $^{\circledR}$ and the compound materials (nickel-titanium/steel elements) offer more favorable activation on account of their lower E-modulus and specific material properties [7, 29-31, 35-38]. In particular the development and application of compound elements for or- $<10^{\circ}$ Derotation eingebogen werden, da sonst die Kräfte und Momente in unphysiologische Bereiche kommen. Für den ArndtMemory-Expander ${ }^{\circledR}$ konnten keine Vorteile gegenüber der Quadhelix und dem Goshgarian-Bogen festgestellt werden. Es zeigten sich keine superelastischen Eigenschaften. Das lineare Verhalten, die relativ hohen Kräfte und Momente und die fehlende klinische Nachjustage machen die Indikation dieser Apparatur fraglich. Der neu entwickelte Compound-Palatinalbogen ${ }^{\circledR}$ zeigte wesentliche Vorteile in der Derotation von Molaren gegenüber den konventionellen Palatinalbögen. Durch die Konstruktion und Anordnung des NiTi-Elementes konnte ein superelastisches Verhalten erzielt werden. In der Expansion war der Compound-Palatinalbogen ${ }^{\circledR}$ vergleichbar mit den konventionellen Palatinalbögen. Der klinische Vorteil liegt in der Nachaktivierbarkeit und der möglichen Behandlung von Asymmetrien.

Schlüsselwörter: Palatinalbogen · Quadhelix · NickelTitan · Goshgarian · Arndt-Memory-Expander ${ }^{\circledR} \cdot$ Compound-Palatinalbogen ${ }^{\circledR} \cdot$ Superelastizität

\section{Einleitung}

Die Anwendung von Lingual- und Palatinalbögen in der kieferorthopädischen Praxis kann als durchaus verbreitet betrachtet werden. Transpalatinalbögen dienen zum einen der dreidimensionalen Einstellung der Molaren, zum anderen aber auch in Verbindung mit weiteren Elementen, wie etwa Implantaten oder Kunststoffplatten im Bereich des Gaumens, als Verankerungseinheit für andere Zähne. Bei der dreidimensionalen Bewegung von Molaren geht es um die Veränderung der Transversalen, die Ausrotation oder die Einstellung des Torques bzw. Kombinationen davon. Die Position der Molaren ist für Angle [2], Andrews [1], McNamara \& Brudon [23], Ricketts [26], Staller [33] und Strang [34] ein wichtiger Faktor für eine gute Behandlung. Eine falsche Position der Molaren macht in den meisten Fällen nach Proffit [25] eine korrekte Einstellung der Okklusion unmöglich.

In Abhängigkeit von der gestellten Indikation der $\mathrm{Pa}$ latinal- und Lingualbögen müssen diese unterschiedlichen Anforderungen entsprechen. Für die Einzelzahnbewegung ist ein System erforderlich, das definierte physiologische Kräfte und Momente auf die Zähne appliziert. Materialien mit eher kleinem E-Modul sind für diese Behandlungsaufgaben geeignet. Konventionelle Transpalatinalbögen wie die Quadhelix und der Goshgarian sind aus Stahlmaterialien, die ein hohes E-Modul aufweisen. Die Aktivierung ist aufgrund des linearen Verhaltens des Materials als problematisch einzustufen, da geringe Aktivierungsabweichungen zu unphysiologisch hohen Kräften und Momenten führen können. Anwenderfreundlicher sind Materialien, die dem Behandler einen gewissen Aktivierungsspielraum lassen. $\mathrm{TMA}^{\circledR}$ und die Compound-Materialien (NiTi-Stahl-Elemente) versprechen aufgrund ihres kleineren E-Moduls 
thodontic therapy may offer essential biomechanical and biological advantages in specific single-tooth movements [27-32, 35-38]. The application of defined, constant physiologic forces is possible with the combination of a nickel-titanium and a steel alloy. Advantages of nickel-titanium alloys, such as superelasticity, can thus be exploited for different orthodontic treatment tasks. The following compound elements have already stood the test in clinical application: compound uprighting spring [31, 36, 38], compound intrusion spring [32, 38], compound torquing archwire $[30,35,38]$, compound retraction archwire [37], and hybrid retraction spring [29].

Besides small, defined forces, it is above all the ideal adjustment of an appropriate $\mathrm{M} / \mathrm{F}$ ratio that is then possible. Bodily tooth movements with the tension uniformly distributed over the entire root area can be achieved in this way $[15,16]$. Complex tooth movements such as palatal root torquing can be achieved without clinically verifiable pathologic side effects. Compound materials are also expected to offer advantages for active tooth movements with a transpalatal arch. The development of a new compound element was therefore one of the aims of this study.

Transpalatal arches are used not only for active tooth movement but also for anchorage purposes. The criteria for the transpalatal arch are dependent on the biomechanical anchorage requirements in each individual patient. As a rule, however, a more rigid material is needed in the interests of stability. Conventional transpalatal arches such as the Goshgarian arch or the quad-helix appliance made of stainless steel are best suited to this purpose. The high E-modulus of these arches ensures the necessary stiffness for the reciprocal forces acting on the molar segments.

The stated indications for transpalatal and lingual arches (active tooth movement and anchorage) clearly illustrate the difficulty of constructing an appliance from one single material. A further aim of the present study was therefore to compare the biomechanical properties of conventional transpalatal arches with those of the Compound palatal $\operatorname{arch}^{\circledR}$. The biomechanical results were moreover to be used to evolve the clinical indications for the different transpalatal arches.

The slot design also plays an important role in the transmission of forces and moments from the bends in the arch. Palatal and lingual archwires are inserted into corresponding molar attachments to comply with the demands of the above-stated indications. Many different types of slot are described in the literature, e.g. by Korkhaus [21], Hotz [18], Wilson \& Wilson [39], and Goshgarian [13]. Some authors recommend soldering the archwires to the bands $[14,17,23,25,26]$. For reasons of biocompatibility, however, laser welding rather than soldering is now recommended for archwire fixation. The und spezifischen Materialverhaltens einen günstigeren Aktivierungsmodus [7, 29-31, 35-38]. Insbesondere die Entwicklung und Nutzung der Compound-Elemente für die orthodontische Therapie können für spezifische Einzelzahnbewegungen wesentliche biomechanische und biologische Vorteile ergeben [27-32, 35-38]. Die Nutzung von definierten und konstanten physiologischen Kräften ist durch die Kombination von NiTi- und Stahllegierung möglich. Vorteile von NiTi-Legierungen, wie Superelastizität, können so für unterschiedliche orthodontische Behandlungsaufgaben eingesetzt werden. Folgende Compound-Elemente sind bereits erfolgreich in klinischer Anwendung: Compound-Aufrichtefeder [31, 36, 38], Compound-Intrusionsfeder [32, 38], Compound-Torquebogen [30, 35, 38], Compound-Retraktionsbogen [37] und Hybrid-Retraktionsfeder [29].

Neben kleinen, definierten Kräften ist vor allen Dingen die ideale Abstimmung eines geeigneten M/F-Verhältnisses möglich. Körperliche Zahnbewegungen mit gleichmäßiger Verteilung der Spannung auf den gesamten Wurzelbereich sind so realisierbar $[15,16]$. Schwierige Zahnbewegungen, wie beispielsweise der palatinale Wurzeltorque, können ohne klinisch verifizierbare pathologische Nebenwirkungen durchgeführt werden. Auch für die Zahnbewegungen mittels Palatinalbogen als aktives Behandlungselement sind Vorteile in der Nutzung von CompoundMaterialien zu erwarten. Die Entwicklung eines weiteren Compound-Elementes war daher ein Ziel dieser Arbeit.

Palatinalbögen werden neben der aktiven Zahnbewegung ebenfalls für die Verankerung eingesetzt. In Abhängigkeit von der für den individuellen Patienten eingesetzten Biomechanik ergeben sich unterschiedliche Anforderungen an die Verankerung mittels Palatinalbögen. In der Regel ist jedoch aufgrund der Stabilität eher ein festes Material geeignet. Hierfür eignen sich besonders die konventionellen Palatinalbögen wie Goshgarian oder Quadhelix aus Stahl. Der hohe E-Modul dieser Bögen gewährleistet die erforderliche Steifigkeit für die auftretenden reziproken Kräfte an den Molarensegmenten.

Die genannten Indikationen der Palatinal- bzw. Lingualbögen (aktive Zahnbewegung und Verankerung) machen deutlich, dass die Realisierung eines Behandlungselementes durch ein Material schwierig ist. Ein weiteres Ziel dieser Arbeit war daher die biomechanische Untersuchung einiger konventioneller Palatinalbögen und ihr Vergleich mit dem Compound-Retraktionsbogen. Weiterhin sollte durch die dargestellten biomechanischen Ergebnisse die klinische Indikation der verschiedenen Palatinalbögen erarbeitet werden.

Neben dem Material des Palatinalbogens ist für die Übertragung der eingestellten Biegungen das verwendete Schloss von Bedeutung. Um die oben genannten Indikationen ausfüllen zu können, werden Palatinal- und Lingualbögen in entsprechende Molarenattachments eingeführt. In der Literatur findet man eine Vielzahl verschiedener Schlösser, so unter anderem von Korkhaus [21], Hotz [18], 
advantage of a rigid connection between slot and band is that the accurate fit between archwire and slot permits the moments to be applied directly to the molars, thus inducing three-dimensional movement. Intraoral activation is, however, still inaccurate. The use of slots offers the clear-cut clinical advantage of permitting good control and active tooth movement. Because of its ergonomic design, the MIA slot [24] permits good handling in situ. A further advantage is the precise transferability of this system to the laboratory, which makes for accurate positioning on the band. As this system cannot be combined with conventional transpalatal arches, it was of no relevance to the Compound palatal $\operatorname{arch}^{\circledR}$. The need for materials to be combined is illustrated by the fact that the quad-helix appliance tends to impair the patient's speech. For this reason a change is made to Goshgarian arches on completion of the active molar movement. Because of its good, simple practicability and the fact that it is a clinically tried-and-tested system, the Goshgarian slot was also used in implementing the Compound palatal $\operatorname{arch}^{\circledR}$.

There are major differences in the design of the quad-helix and of the Goshgarian arch. The advantage of the quad-helix is clearly in its greater flexibility. The additional arms make for a broader treatment spectrum. Not only symmetric problems but also the clinically more frequent asymmetric discrepancies can be treated by intercepting the reciprocal forces through unilateral bending of the respective arm. The special advantage of the Goshgarian arch is in its more compact design. The aim of this study was to combine the advantages of both systems into one new system.

\section{Problems}

Transpalatal arches are usually made of a $0.8-0.9 \mathrm{~mm}$ stainless steel wire that is adapted to the patient's specific anatomic requirements. The Goshgarian arch has only one open U-loop $[13,25]$ and is therefore exceptionally rigid, whereas the quad-helix, for example, which has four loops and thus a correspondingly longer wire, is less stiff. Transpalatal arches made of $\mathrm{TMA}^{\circledR}$ wire $[7,19,20]$ also offer lower force transmission, since the E-modulus of this material is only half as high as that of stainless steel. As Jäger et al. [20] showed, it is almost impossible to bend such an arch in a completely passive form. However, the stiffness of the wire also makes it very difficult for the practitioner to carry out activations and reactivations that are still within the tolerance range of forces indicated for bodily movement of teeth [4-6, 12, 17]. A solution to this problem may be provided by the Arndt memory expander ${ }^{\circledR}[3]$ (GAC, Central Islip, NY, USA), as it incorporates superelastic material.

Being aware of the problems associated with transpalatal arches and with activation and reactivation, we undertook to develop an arch whose application pro-
Wilson \& Wilson [39] und Goshgarian [13]. Einige Autoren empfehlen auch das Anlöten der Bögen an die Bänder [14, 17, 23, 25, 26]. Aus Biokompatibilitätsgründen sollte heute jedoch auf das Löten verzichtet und die Bögen über Laserschweißverfahren befestigt werden. Vorteil einer festen Verbindung zwischen Schloss und Band ist die Momentschlüssigkeit des Bogens mit dem Molaren, so dass auch wirklich dreidimensionale Zahnbewegungen durchgeführt werden können. Die intraorale Aktivierung ist und bleibt jedoch ungenau. Für eine gute Kontrolle und aktive Durchführung von Zahnbewegungen ist die Anwendung von Schlössern von wesentlichem klinischen Vorteil. Dies ermöglicht eine genauere Kontrolle der durchgeführten Aktivierungen. Das MIA-Schloss [24] zeigt durch seine ergonomische Form eine sehr gute Handhabung am Patienten. Ein weiterer Vorteil ergibt sich aus der genauen Übertragbarkeit des Systems in das Labor. Eine sehr gute Passgenauigkeit kann dadurch erzielt werden. Da dieses System nicht mit konventionellen Transpalatinalbögen kombinierbar ist, hatte es für die Verankerung des Compound-Palatinalbogen ${ }^{\circledR}$ keine Relevanz. Die Notwendigkeit der Kombinierbarkeit ergibt sich aus der Tatsache, dass die Quadhelix für die Aussprache der Patienten eher ein störendes Behandlungsgerät ist. In vielen Fällen wird daher nach der aktiven Bewegung der Molaren auf Goshgarian-Bögen gewechselt. Aufgrund der guten, einfachen Praktikabilität und der Tatsache, dass es sich um ein klinisch bewährtes System handelt, wurde das Goshgarian-Schloss auch bei der Realisierung des Compound-Palatinalbogen ${ }^{\circledR}$ verwendet.

Bei der Konstruktion von Palatinalbögen kann im Wesentlichen zwischen der Quadhelix und dem GoshgarianBogen unterschieden werden. Der Vorteil der Quadhelix ist sicherlich in der höheren Flexibilität zu sehen. Durch die zusätzliche Konstruktion der Arme ergibt sich ein größeres Behandlungsspektrum. Neben symmetrischen Behandlungsaufgaben lassen sich ebenfalls die klinisch häufigeren Asymmetrien lösen. Dies gelingt durch Abfangen der reziproken Kräfte durch einseitiges Anbiegen des jeweiligen Armes. Der Vorteil des Goshgarian-Bogens ist insbesondere in der grazileren Konstruktion zu sehen. Ziel dieser Arbeit war die Vorteile beider Systeme in einer Neukonstruktion nutzbar zu machen.

\section{Problemstellung}

Typischerweise werden Palatinalbögen aus einem 0,8-0,9 mm starken Edelstahlbogen hergestellt, der jeweils an die entsprechenden anatomischen Verhältnisse des zu behandelnden Patienten angepasst wird. Als besonders steif kann dabei der Goshgarian-Bogen bezeichnet werden, der nur einen offenen U-Loop besitzt [13, 25], während etwa die Quadhelix mit ihren vier Schlaufen und damit einem entsprechend längeren Draht als weniger steif betrachtet werden kann. Palatinalbögen aus TMA ${ }^{\circledR}$-Draht $[7,19,20]$ versprechen ebenfalls eine geringere Kraftübertragung, da der 
tects the teeth from excessive forces and moments. However, the arch was to continue to permit the functions of expansion, rotation and finally torque transmission. In addition, it had naturally to offer the practitioner the opportunity for reactivation.

The aim of the present study was a biomechanical investigation of the Compound palatal $\operatorname{arch}^{\circledR}$ to verify the anticipated forces and moments with respect to transversal movement, derotation and torque. For comparison of the data evaluated for the Compound palatal $\operatorname{arch}^{\circledR}$ and for an improved clinical indication, some commercially available conventional transpalatal arches were to be investigated.

A further issue was the practicability of this appliance in clinical use. In this respect, the Compound palatal $\operatorname{arch}^{\circledR}$ was to be used in patients undergoing orthodontic therapy.

\section{Material and Methods \\ Development and Design of the Compound Palatal $\mathrm{Arch}^{\circledR}$}

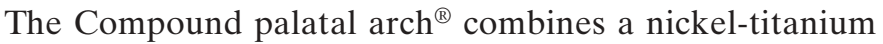
and a steel element. The design was based on finite element calculations of compound materials and bending measurements of nickel-titanium materials, offering a precise characterization of each individual material [15, 16]. It follows from the finite element calculations and from the practical assessment of bending of superelastic

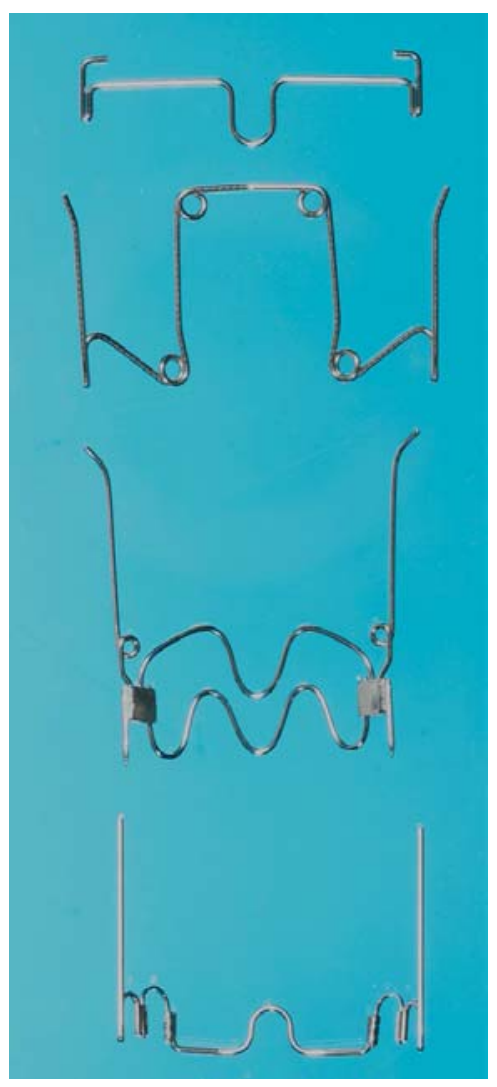

Figure 1. The measured palatal arches. From top to bottom: Goshgarian arch, quad-helix, Arndt memory expander ${ }^{\circledR}$, and Compound palatal $\operatorname{arch}^{\circledR}$.

Abbildung 1. Die vermessenen Palatinalbögen, von oben nach unten: Goshgarian-Bogen, Quadhelix, Arndt-Memory-Expander ${ }^{\circledR}$, Compound-Palatinalbogen ${ }^{\circledR}$.
E-Modul dieses Drahtes nur etwa halb so hoch ist wie der von Stahl. Wie Jäger et al. [20] zeigen konnten, ist es praktisch unmöglich, einen derartigen Bogen völlig passiv zu biegen. Die Steifheit des Drahtes macht es aber auch dem Anwender sehr schwer, Aktivierungen und Nachaktivierungen durchzuführen, die noch im Toleranzbereich der Kräfte liegen, wie man sie für eine körperliche Bewegung von Zähnen erwartet [4-6, 12,17]. Eine Lösung dieses Problems versprechen die Arndt-Memory-Expander ${ }^{\circledR}$ [3] der Firma GAC (Central Islip, NY, USA), da sie superelastische Materialien beinhalten.

In Kenntnis der Probleme mit den Palatinalbögen und der Problematik bei der Aktivierung und Nachaktivierung haben wir uns die Aufgabe gestellt, einen Palatinalbogen zu entwickeln, der in der Anwendung die Zähne vor übermäßigen Kräften und Momenten schützt. Dabei soll der Palatinalbogen weiterhin die Aufgaben der Expansion, der Ausrotation und schließlich die Übertragung des Torques erfüllen können. Darüber hinaus muss selbstverständlich die Nachaktivierungsmöglichkeit durch den Anwender gegeben sein.

Zur Verifizierung der zu erwartenden Kräfte und Momente war Ziel dieser Arbeit die biomechanische Untersuchung des Compound-Palatinalbogens ${ }^{\circledR}$. Berücksichtigt wurden die Transversalbewegung, Derotation und der Torque. Zum Vergleich der beim Compound-Palatinalbogen ${ }^{\circledR}$ evaluierten Daten und für eine bessere klinische Indikationsstellung sollten einige auf dem Markt befindliche konventionelle Palatinalbögen untersucht werden.

Eine weitere Fragestellung dieser Arbeit ergab sich im Hinblick auf die Praktikabilität und den klinischen Einsatz am Patienten. Hierfür sollte der Compound-Palatinalbogen ${ }^{\circledR}$ an in kieferorthopädischer Behandlung befindlichen Patienten eingesetzt werden.

\section{Material und Methode \\ Entwicklung und Konstruktion des Compound- \\ Palatinalbogens ${ }^{\circledR}$}

Der Compound-Palatinalbogen ${ }^{\circledR}$ besteht aus einem NiTiund einem Stahlelement. Die Konstruktion basierte auf Finite-Elemente-Berechnungen von Compound-Elementen und Biegemessungen bei NiTi-Materialien, die die einzelnen Materialkomponenten genauer charakterisieren [15, 16]. In Anlehnung an die Finite-Elemente-Berechnungen und die praktisch durchgeführten Biegemessungen an superelastischen Materialien von Hempowitz et al. [15, 16] tritt bei diesen Materialien die größte Verbiegung an der Einspannstelle auf.

Neben den grundlegend verschiedenen Biegelinien bei Stahl und NiTi zeigt sich auch bei den Dehnungen ein sehr großer Unterschied. Die Dehnungen unterscheiden sich sowohl in der Amplitude wie auch in der Struktur des dreidimensionalen Dehnungsfeldes. Die erhöhten Dehnungen sind bei NiTi-Legierungen viel stärker auf lokale Bereiche 


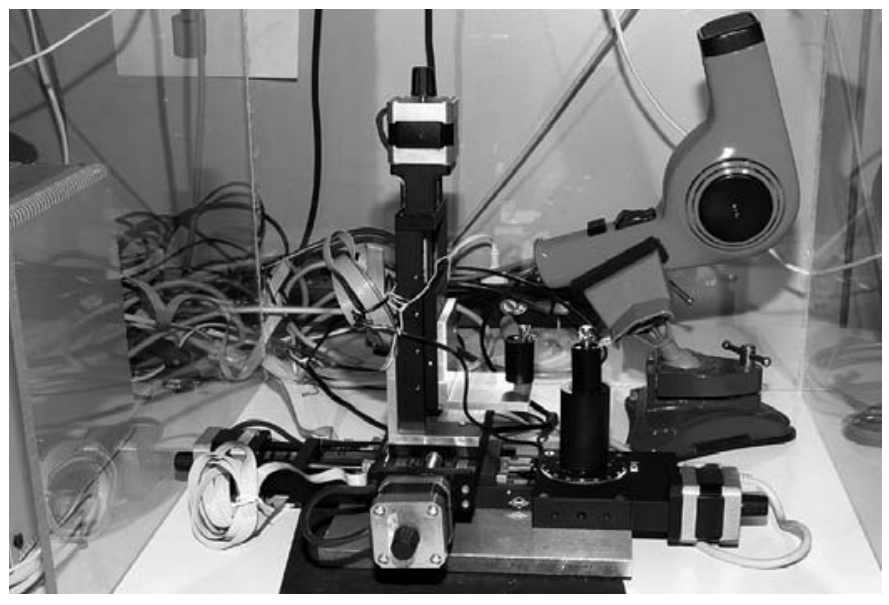

Figure 2. Biomechanical measuring apparatus ( $4^{\circ}$ of freedom) within an acrylic casing.

Abbildung 2. Biomechanischer Messplatz im Plexiglasgehäuse. Der Messplatz besitzt vier Freiheitsgrade.

materials by Hempowitz et al. $[15,16]$ that the greatest deflection of these materials occurs at the clamping point.

Besides the fundamentally different bending curves for stainless steel and nickel-titanium, there are also major differences in strain, both in the amplitude and in the structure of the three-dimensional strain field. In comparison with linear materials, the increased strains are far more localized in the case of nickel-titanium alloys. Strictly speaking, this applies to all non-linear materials. A purely elastic, linear material with no pseudoplastic plateau shows a far more homogeneous strain field than the superelastic nickel-titanium alloys. The maximum amplitude of the linear material is also considerably lower than that of the nickel-titanium alloys. Therefore, a palatal arch was developed with the superelastic material located as close as possible to the respective slot. To achieve the lowest possible forces and moments, a $7 \mathrm{~mm}$ long superelastic $0.016^{\prime \prime} \times 0.022^{\prime \prime}$ Titanol $\mathrm{SE}^{\circledR}$ section (Forestadent ${ }^{\circledR}$, Pforzheim, Germany) was integrated into the structure. Under these conditions the Compound palatal $\operatorname{arch}^{\circledR}$ was developed. The two nickel-titanium elements are joined by a $0.8 \mathrm{~mm}$ steel wire. This connecting section incorporating a U-loop can also be used to reactivate the transversal width (Figure 1).

\section{Biomechanical Measurement Set-up}

The testing of forces and moments on insertion of the palatal arches was performed with two force-moment sensors, each of which could register simultaneously both the forces measured in the $\mathrm{x}-, \mathrm{y}-$ and $\mathrm{z}$-axes and the relevant moments in these axes. These six-component sensors were fixed to measuring tables controlled by stepping motors (Figures 2 and 3 ).

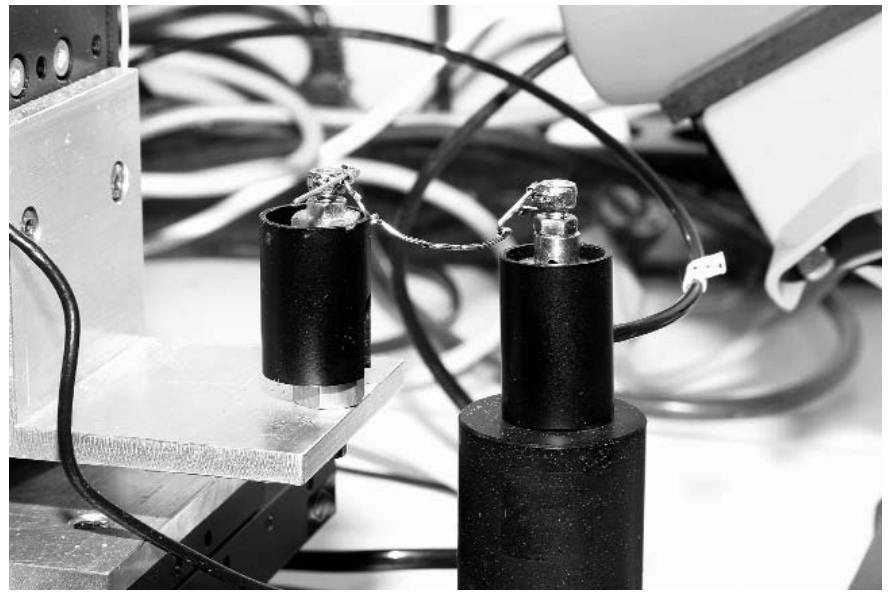

Figure 3. Sensors with the quad-helix which is secured with ligatures.

Abbildung 3. Sensoren mit Quadhelix. Diese ist durch Ligaturen fixiert.

beschränkt als bei den linearen Materialien. Dies gilt streng genommen für alle nichtlinearen Materialien. Ein rein elastisches, lineares Material ohne pseudoplastisches Plateau zeigt ein weitaus homogeneres Dehnungsfeld als die superelastischen NiTi-Legierungen. Die Maximalamplitude des linearen Materials ist ebenso erheblich niedriger als bei den NiTi-Legierungen. Es wurde daher ein Palatinalbogen entwickelt, bei dem sich superelastisches Material so nahe wie möglich an dem jeweiligen Schloss befindet. Zur Erreichung von möglichst kleinen Kräften und Momenten ist jeweils ein $7 \mathrm{~mm}$ langes superelastisches Stück Titanol $\mathrm{SE}^{\circledR}$, Dimension 0.016" $\times 0.022^{\prime \prime}$ der Firma Forestadent ${ }^{\circledR}$ (Pforzheim) integriert worden. Unter diesen Voraussetzungen wurde der Compound-Palatinalbogen ${ }^{\circledR}$ entwickelt. Verbunden sind beide NiTi-Elemente mit einem Stahldraht der Stärke $0,8 \mathrm{~mm}$. Dieses Zwischenstück mit einer U-Schlaufe kann auch zur Nachaktivierung der transversalen Breite verwendet werden (Abbildung 1).

\section{Biomechanischer Messplatz}

Zur Untersuchung der Kräfte und Momente bei dem Einsatz von Palatinalbögen wurden zwei Kraft-MomentenSensoren verwendet, die jeweils gleichzeitig die gemessenen Kräfte in x-, y- und z-Richtung sowie die dazugehörenden Momente um x, y und z erfassten. Diese Sechs-Komponenten-Sensoren befanden sich auf Messtischen, die von Schrittmotoren gesteuert wurden (Abbildungen 2 und 3).

Zur Erzielung einer hohen Steifigkeit hatte der Messplatz nur vier Freiheitsgrade. Der simulierte Zahn 1 (Zahn 26) (Abbildung 4) konnte translatorisch bewegt werden in $\mathrm{x}$-, y- und z-Richtung (Abbildung 4). Der simulierte Zahn 2 (Zahn 16) konnte um die z-Achse rotieren (Abbildung 5). Die auf diese Weise erzielte Steifigkeit betrug $4 \times 10^{+4}$ $\mathrm{N} / \mathrm{mm}$. 


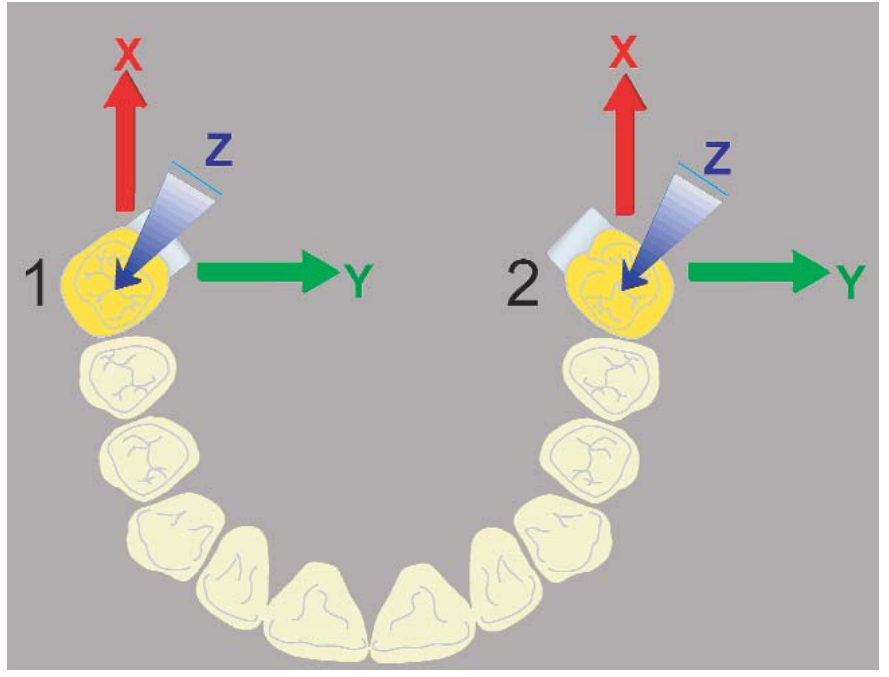

Figure 4. Coordinate system of forces (= axes). Left: sensor 1 (tooth 26), right: sensor 2 (tooth 16). Sensor 1 permits the translation.

Abbildung 4. Koordinatensystem der Kräfte (= Achsen). Links: Sensor 1 (Zahn 26), rechts: Sensor 2 (Zahn 16). Sensor 1 ermöglicht die Translation.

To achieve high stiffness, the measurement set-up had only four degrees of freedom. Simulated tooth 1 (tooth 26) (Figure 4) could be moved translatorily in $\mathrm{x}$-, y- and z-directions (Figure 4). Simulated tooth 2 (tooth 16) could rotate around the z-axis (Figure 5). The stiffness achieved in this way was $4 \times 10^{+4} \mathrm{~N} / \mathrm{mm}$.

A linear table LM60 (Pörschke, Höchst, Germany) was used for the test set-up. Rotation was achieved with DTM60 rotary tables (Pörschke, Höchst, Germany) which, like the linear tables, were controlled with great accuracy by stepping motors [27]. The force sensor had a measuring range of $\pm 10 \mathrm{~N}$ with a resolution of 10 Bit, i.e. ca. $\pm 1 / 100 \mathrm{~N}$. The range of the moments was $\pm 0.1 \mathrm{Nm}$, and the resolution $\pm 0.1 \mathrm{Nmm}$.

In addition to this high accuracy, the play within the molar attachments influenced the measured values. For this reason, the torque values were also checked after insertion of the transpalatal arches into the measurement set-up. Since the accuracy of fit within the slot was different for each type of transpalatal arch, it was here that the greatest measurement error was expected to occur. In some cases the loss of torque in the attachment was as much as $5^{\circ}$. Although this was largely offset by fixation with the steel ligature, it led to unexpected forces and moments. These particular circumstances had the following influence on accuracy: forces $\pm 0.01 \mathrm{~N}$, moments \pm 0.1 $\mathrm{Nmm}$, deflection $\pm 0.1 \mathrm{~mm}$, angular measurements $\pm 0.1^{\circ}$.

Because of the described fitting inaccuracies, the error was as much as $5 \%$ in rare cases. Since nickel-titanium alloys are used in both the Arndt memory

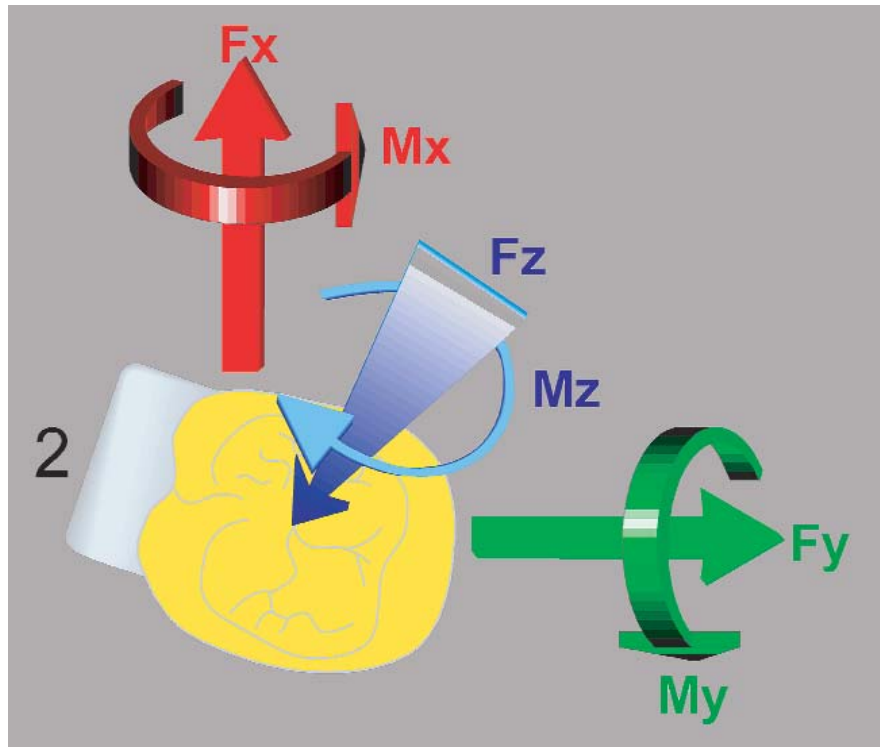

Figure 5. Coordinate system of forces and moments (sensor 2). This sensor rotates (tooth 16$) . \mathrm{Fx}=+$ distalization - mesialization; Fy $=+$ expansion - compression; $\mathrm{Fz}=+$ intrusion - extrusion; $\mathrm{Mx}=+$ palatal root torque - buccal root torque; $M y=+$ mesial tipping - distal tipping; $M z=+$ mesial rotation - distal rotation.

Abbildung 5. Koordinatensystem der Kräfte und Momente (Sensor 2). Dieser Sensor rotiert (Zahn 16). $\mathrm{Fx}=+$ Distalisation - Mesialisation; Fy = + Expansion -Kompression; $\mathrm{Fz}=+$ Intrusion - Extrusion; $\mathrm{Mx}=+$ palatinaler Wurzeltorque - bukkaler Wurzeltorque; $\mathrm{My}=+$ Mesialkippung - Distalkippung; $\mathrm{Mz}=+$ Mesialrotation - Distalrotation.

Bei dem Versuchsaufbau wurden die Lineartische LM60 (Pörschke, Höchst) verwendet. Zur Rotation kamen Drehtische DTM60 (Pörschke, Höchst) zum Einsatz, die ebenfalls wie die Lineartische über einen Schrittmotor mit einer hohen Genauigkeit gesteuert wurden [27]. Der Kraftsensor besaß einen Messbereich von $\pm 10 \mathrm{~N}$ mit einer Auflösung von $10 \mathrm{Bit}$, das heißt ca. \pm 1/100 N. Der Bereich der Momente betrug $\pm 0,1 \mathrm{Nm}$, die Auflösung $\pm 0,1 \mathrm{Nmm}$.

Neben dieser hohen Genauigkeit beeinflusste die Spielfreiheit der Molarenschlösser das Messergebnis. Aus diesem Grund wurden die Torquewerte auch nach dem jeweiligen Einsetzen der Bögen in die Messapparatur kontrolliert. Da jedes Fabrikat der Palatinalbögen unterschiedliche Passgenauigkeiten aufwies, war hierbei der größte Fehler einzukalkulieren. Teilweise betrug der Torqueverlust im Schloss bis zu $5^{\circ}$. Dieser wurde durch die Stahlligatur weitgehendst ausgeglichen, führte jedoch zu unerwarteten Kräften und Momenten. Diese Besonderheiten hatten einen Einfluss auf die Genauigkeit: Kräfte $\pm 0,01$ N, Momente $\pm 0,1 \mathrm{Nmm}$, Wege $\pm 0,1 \mathrm{~mm}$ und Winkel $\pm 0,1^{\circ}$.

Durch die beschriebenen Passungenauigkeiten konnte der Fehler in selten Fällen 5\% betragen. Da sowohl der Arndt-Memory-Expander ${ }^{\circledR}$ [3] als auch der Compound-Palatinalbogen ${ }^{\circledR}$ Nickel-Titan-Legierungen verwenden, befand sich der gesamte Messaufbau in einem Plexiglas- 
expander ${ }^{\circledR}[3]$ and the Compound palatal $\operatorname{arch}^{\circledR}$, the entire measuring set-up was isolated in an acrylic casing that could be heated to a constant temperature of $37^{\circ} \mathrm{C}$. The sensors were temperature-compensated, with no further calibration being required. All transpalatal arches and quad-helix appliances were made of stainless steel and measured at room temperature.

Tested Movements: Transversal expansion without root torque, 0-5 $\mathrm{mm}$; transversal expansion with root torque, $0-5 \mathrm{~mm}$; rotation, $0-30^{\circ}$.

Each measurement was carried out four times and the mean value was used for this publication. The measured values were within a very narrow range with a scatter of less than $3 \%$ for all measurements, providing the spring was not clamped and unclamped between tests, the ligatures were tightly secured, and no plastic deformation occurred.

Figures 4 and 5 show the spatial position of the coordinates in the maxilla.

Investigated Transpalatal Arches: Quad-helix, stainless steel, size 3 (Forestadent ${ }^{\circledR}$, Pforzheim, Germany), quadhelix, size 3 (3M Unitek ${ }^{\circledR}$, Monrovia, CA, USA) (Unitek ${ }^{\mathrm{TM}}$ MIA system [24]), Arndt memory expander ${ }^{\circledR}$, size 39 (GAC, Central Islip, NY, USA), Compound palatal $\operatorname{arch}^{\circledR}$, medium size (Forestadent ${ }^{\circledR}$, Pforzheim, Germany), and Goshgarian transpalatal arch $\left(\right.$ Forestadent $^{\circledR}$, Pforzheim, Germany) for direct comparison.

Not all possible movements are shown for the stainless steel Goshgarian arch because its force/deflection rate was so high that adjustment to physiologic forces was virtually impossible during application. Rotation as the test movement described above could not be performed with this arch as the results exceeded the limiting value of the sensors.

The forces developed in the typical stainless steel quad-helix and in the Unitek ${ }^{\mathrm{TM}}$ MIA quad-helix hardly differed. They are therefore both discussed under the term "quad-helix".

The diagrams represent the forces and moments registered by sensor 2 (tooth 16). Each measurement covered the force components in the $\mathrm{x}, \mathrm{y}$ and $\mathrm{z}$ axes. The moments registered in the $\mathrm{x}$-, $\mathrm{y}$ - and $\mathrm{z}$-axes are also shown (Figure 5). For continuous control of both sensors, the force value $(/ \mathrm{F} /)$ was ascertained and checked according to the equilibrium condition. However, it is not shown here.

\section{Results}

Goshgarian Arch

a) Transversal Expansion without Torque (Figures $6 a$ to $6 c$ )

The Goshgarian arch proved in the measurements to be the stiffest palatal arch. A $5 \mathrm{~mm}$ activation generated a force of $8 \mathrm{~N}$ (Fy) on the unloading curve (Figure 6a). Since the forces were linear, a stiffness of $1.6 \mathrm{~N} / \mathrm{mm}$ was gehäuse, das auf eine konstante Temperatur von $37^{\circ} \mathrm{C}$ aufgeheizt werden kann. Die Sensoren waren temperaturkompensiert, eine weitere Kalibrierung war nicht erforderlich. Alle Palatinalbögen und Quadhelices aus Stahl wurden bei Raumtemperatur vermessen.

In dieser Untersuchung getestete Bewegungen: die transversale Erweiterung ohne Wurzeltorque, 0-5 mm; die transversale Erweiterung mit Wurzeltorque, 0-5 mm; die Rotation, $0-30^{\circ}$.

Jede Messung wurde viermal durchgeführt und der Mittelwert für diese Publikation verwendet. Die Streuung der Messwerte war sehr gering und lag bei allen Messungen unterhalb von 3\%, wenn die Federn zwischen den Versuchen nicht aus- und eingespannt wurden, die Ligaturen fest angezogen waren und es nicht zu einer plastischen Deformation kam.

Die räumliche Lage der Koordinaten im Oberkiefer zeigen die Abbildungen 4 und 5.

Untersuchte Palatinalbögen: Quadhelix aus Stahl, Größe 3 (Forestadent ${ }^{\circledR}$, Pforzheim); Quadhelix, Größe 3 (3M Unitek ${ }^{\circledR}$, Monrovia, CA, USA) (Unitek ${ }^{\mathrm{TM}}$ MIA-System [24]); Arndt-Memory-Expander ${ }^{\circledR}$, Größe 39 (GAC, Central Islip, NY, USA); Compound-Palatinalbogen ${ }^{\circledR}$, Größe mittel (Forestadent ${ }^{\circledR}$, Pforzheim). Der GoshgarianBogen (Forestadent ${ }^{\circledR}$, Pforzheim) sollte als Vergleichsbogen dienen.

Bei dem Goshgarian-Bogen aus Stahl werden nicht alle Bewegungsmöglichkeiten dargestellt, da die Kraft-/ Biegerate dieses Bogens so hoch war, dass bei der Anwendung ein Einstellen auf physiologische Kräfte praktisch nicht möglich war. Mit diesem Bogen konnte die oben beschriebene Testbewegung Rotation nicht durchgeführt werden, da sie die Grenzwerte der Sensoren überschritt.

Die Kraftentwicklung der typischen Quadhelix aus Stahl und der Unitek ${ }^{\mathrm{TM}}$ MIA-Quadhelix unterschieden sich kaum. Daher wurden beide unter dem Begriff Quadhelix zusammengefasst.

Die dargestellten Diagramme sind die Kräfte und Momente des Sensors 2 (Zahn 16). Jede Messung enthält die Kraftkomponenten in $\mathrm{x}-$, y- und z-Richtung. Zusätzlich werden die Momente um x, y und $\mathrm{z}$ dargestellt (Abbildung 5). Zur ständigen Überprüfung beider Sensoren wurde der Betrag der Kraft (/F/) gebildet und entsprechend der Gleichgewichtsbedingung kontrolliert, jedoch nicht dargestellt.

\section{Ergebnisse \\ Goshgarian-Bogen}

a) Transversale Erweiterung ohne Torque (Abbildungen $6 a$ bis $6 c$ )

Der Goshgarian-Bogen erwies sich als der steifste Bogen bei den Vermessungen. Eine Aktivierung von $5 \mathrm{~mm}$ erzeugte eine Kraft auf der Entlastungskurve von 8 N (Fy) (Abbildung 6a). Da die Kräfte linear waren, ergab sich somit eine Steifigkeit von 1,6 N/mm bei der Kompressionsbewegung. Die Drehmomente stiegen bei dieser Kompres- 

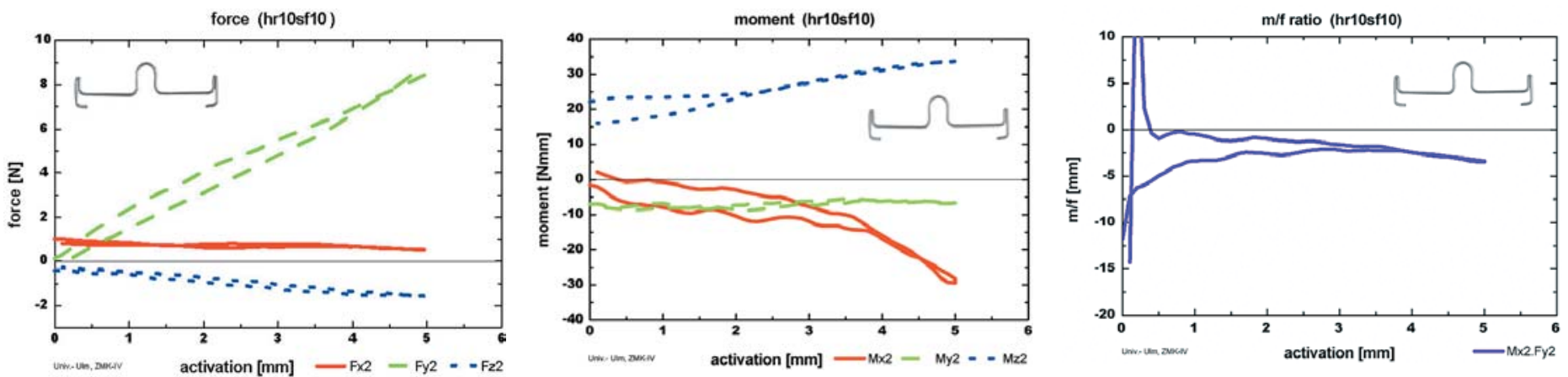

Figures $6 \mathrm{a}$ to $6 \mathrm{c}$. Goshgarian arch without torque (a: forces, b: moments, c: Mx/Fy).

Abbildungen $6 a$ bis $6 c$. Goshgarian-Bogen ohne Torque (a: Kräfte, b: Momente, c: Mx/Fy).
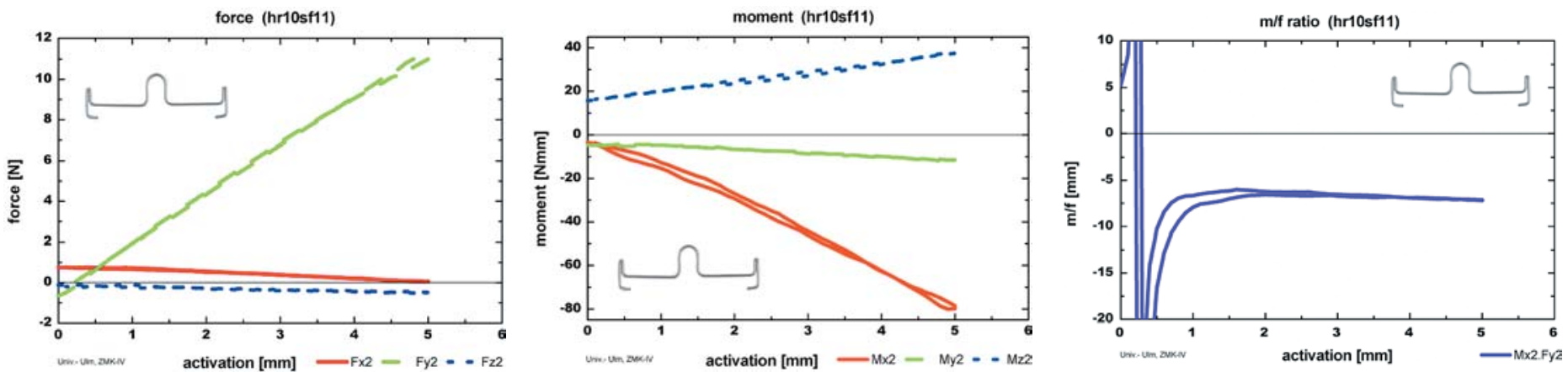

Figures 7a to 7c. Goshgarian arch with torque (a: forces, b: moments, c: Mx/Fy).

Abbildungen 7a bis 7c. Goshgarian-Bogen mit Torque (a: Kräfte, b: Momente, c: Mx/Fy).

Note on Figures 6 to 15: To distinguish the loading from the unloading curve: During loading and unloading the unloading curve (unloading) ends earlier.

Anmerkung zu den Abbildungen 6 bis 15: Zur Unterscheidung der Hinlauf-von der Rücklaufkurve bei der Belastung und Entlastung endet die Rücklaufkurve (Entlastung) früher.

registered during compression. With this compression around the $\mathrm{x}$-axis, the moments increased to $-30 \mathrm{Nmm}$ (Mx) (Figure 6b). Purely transverse activation accordingly induced expansion but not bodily molar movement (Figure 6c). The moment (Mx) caused buccal tipping of the molar crowns. As the force increased, a mesially rotating moment $(\mathrm{Mz})$ occurred.

\section{b) Transversal Expansion with Added Torque (Fig- ures 7 a to $7 c$ )}

Bending in buccal root torque further increased the stiffness of the Goshgarian arch. A $5 \mathrm{~mm}$ compression movement produced a force (Fy) of $12 \mathrm{~N}$ (Figure 7a). The stiffness was thus $2.4 \mathrm{~N} / \mathrm{mm}$. The moments $(\mathrm{Mx})$ increased to $80 \mathrm{Nmm}$ as a result of the bent-in torque (Figure $7 \mathrm{~b}$ ), suggesting a bodily movement at least in view of the $\mathrm{M} / \mathrm{F}$ ratio. To remain within physiologic limits, activations of more than 1-1.5 mm should clearly be avoided. A mesially rotating moment $(\mathrm{Mz})$ occurred with this activation too. sion um die $\mathrm{x}$-Achse auf $-30 \mathrm{Nmm}$ (Mx) (Abbildung 6b). Bei rein transversaler Aktivierung kam es demnach zur Expansion, aber nicht zu einer körperlichen Bewegung der Molaren (Abbildung 6c). Das Drehmoment Mx führte zu einer Kippung der Molarenkronen nach bukkal. Mit dem Anstieg der Kräfte erfolgte ein mesial rotierendes Drehmoment (Mz).

\section{b) Transversale Erweiterung mit Torque (Abbildungen $7 a$ bis $7 c$ )}

Durch das Einbiegen eines bukkalen Wurzeltorques nahm die Steifigkeit des Goshgarian-Bogens erneut zu. Eine Kompressionsbewegung von $5 \mathrm{~mm}$ erzeugte eine Kraft (Fy) von $12 \mathrm{~N}$ (Abbildung 7a). Damit betrug die Steifigkeit 2,4 N/mm. Die Drehmomente stiegen durch das Einbiegen des Torques (Mx) auf $80 \mathrm{Nmm}$ (Abbildung 7b), was zumindest durch das M/F-Verhältnis auf eine körperliche Bewegung schließen ließ (Abbildung 7c). Um im physiologischen Bereich zu sein, sollten sicherlich keine Aktivierungen über 1-1,5 $\mathrm{mm}$ vorgenommen werden. Es entstand 

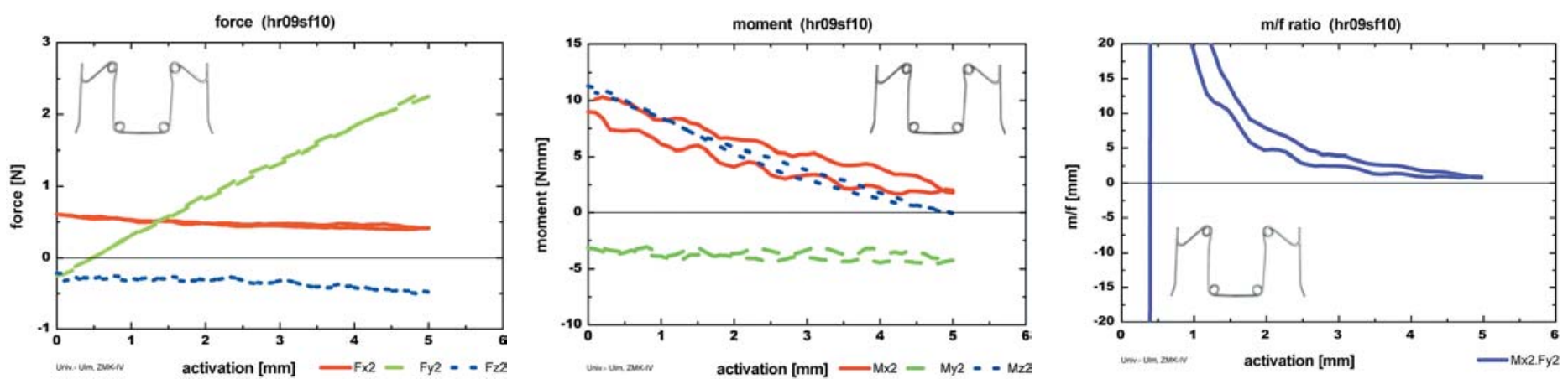

Figures 8a to 8c. Stainless steel quad-helix (3M Unitek $\left.{ }^{\circledR}\right)$ and Unite ${ }^{\text {TM }}$ MIA quad-helix with expansion but no torque. Representation of forces and moments (a: forces, b: moments, c: Mx/Fy).

Abbildungen 8a bis 8c. Stahl-Quadhelix (3M Unitek $\left.{ }^{\circledR}\right)$ und Unitek ${ }^{\text {TM }}$ MIA Quadhelix Arch, Expansion ohne Torque. Darstellung der Kräfte und Momente (a: Kräfte, b: Momente, c: Mx/Fy).
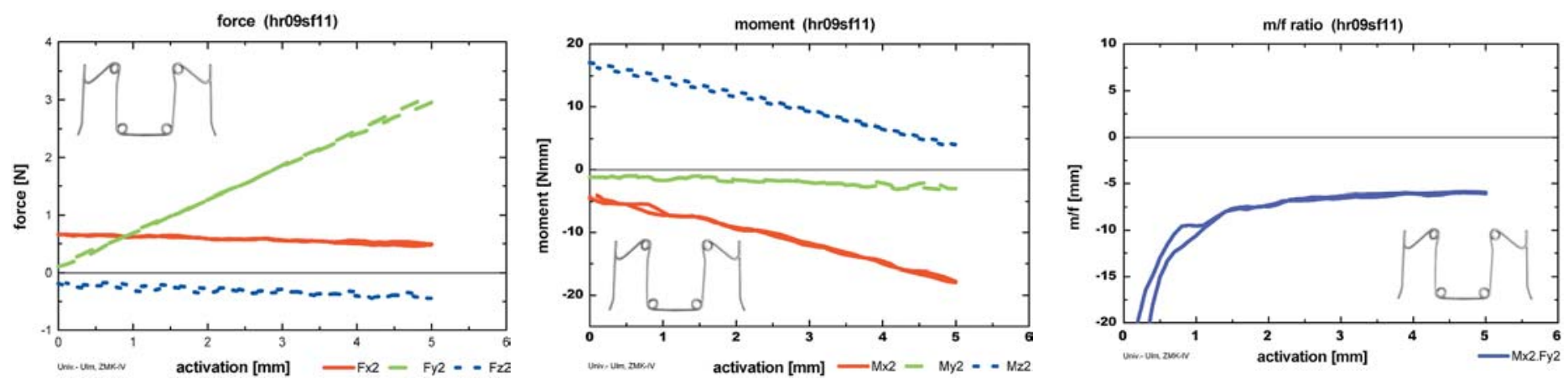

Figures $9 \mathrm{a}$ to $9 \mathrm{c}$. Stainless steel quad-helix (3M Unitek ${ }^{\circledR}$ ) and Unitek ${ }^{\text {TM }}$ MIA quad-helix with expansion and torque. Representation of forces and moments (a: forces, b: moments, c: Mx/Fy).

Abbildungen 9a bis 9c. Stahl-Quadhelix (3M Unitek ${ }^{\circledR}$ ) und Unitek ${ }^{\mathrm{TM}}$ MIA Quadhelix Arch, Expansion mit Torque. Darstellung der Kräfte und Momente (a: Kräfte, b: Momente, c: Mx/Fy).

\section{c) Rotation}

This test could not be carried out, since the resulting moments exceeded the limits of the sensors. A $20^{\circ}$ rotation produced a moment of $120 \mathrm{Nmm}$.

\section{Quad-helix}

a) Transversal Expansion without Root Torque (Figures 8 a to $8 c$ )

With a $5 \mathrm{~mm}$ expansion the transversal force (Fy) was 2.5 $\mathrm{N}$ (Figure 8a). The stiffness was $0.5 \mathrm{~N} / \mathrm{mm}$. These results showed that the quad-helix could not be inserted in a totally passive state. Initially a palatal root torque of 10 $\mathrm{Nmm}$ was registered. The moment $(\mathrm{Mx})$ decreased from $10 \mathrm{Nmm}$ to $2 \mathrm{Nmm}$ (Figure $8 \mathrm{~b}$ ). This moment did not result in bodily molar movement (Figure 8c). The moment around the $\mathrm{z}$-axis $(\mathrm{Mz})$ fell from $11 \mathrm{Nmm}$ to $0 \mathrm{Nmm}$, corresponding to a distally rotating moment on the molars.

b) Transversal Expansion with Added Torque (Figures 9 a to $9 c$ )

The initially active buccal root torque ( $\mathrm{Mx}$ ) was $-4 \mathrm{Nmm}$. Stress-free insertion could no longer be controlled in this auch bei dieser Messung ein mesial rotierendes Drehmoment (Mz).

\section{c) Rotation}

Dieser Versuch konnte nicht durchgeführt werden, da die jeweils auftretenden Momente die Grenzen der Sensoren überschritten. Eine Rotation von $20^{\circ}$ führte zu einem Moment von $120 \mathrm{Nmm}$.

\section{Quadhelix}

a) Transversale Erweiterung ohne Wurzeltorque (Abbildungen 8 a bis $8 c$ )

Bei einer Expansion von $5 \mathrm{~mm}$ betrug die transversale Kraft (Fy) 2,5 N (Abbildung 8a). Die Steifigkeit betrug 0,5 N/mm. Die Daten zeigten, dass die Quadhelix nicht spannungsfrei eingesetzt werden konnte. Initial zeigte sich ein palatinaler Wurzeltorque von $10 \mathrm{Nmm}$. Das Drehmoment $\mathrm{Mx}$ reduzierte sich von $10 \mathrm{Nmm}$ auf $2 \mathrm{Nmm}$ (Abbildung 8b). Dieses Drehmoment führte nicht zu einer körperlichen Bewegung des Molaren (Abbildung 8c). Das Drehmoment um die z-Achse Mz sank von $11 \mathrm{Nmm}$ auf $0 \mathrm{Nmm}$, was einem distal rotierenden Moment für den Molaren entspricht. 

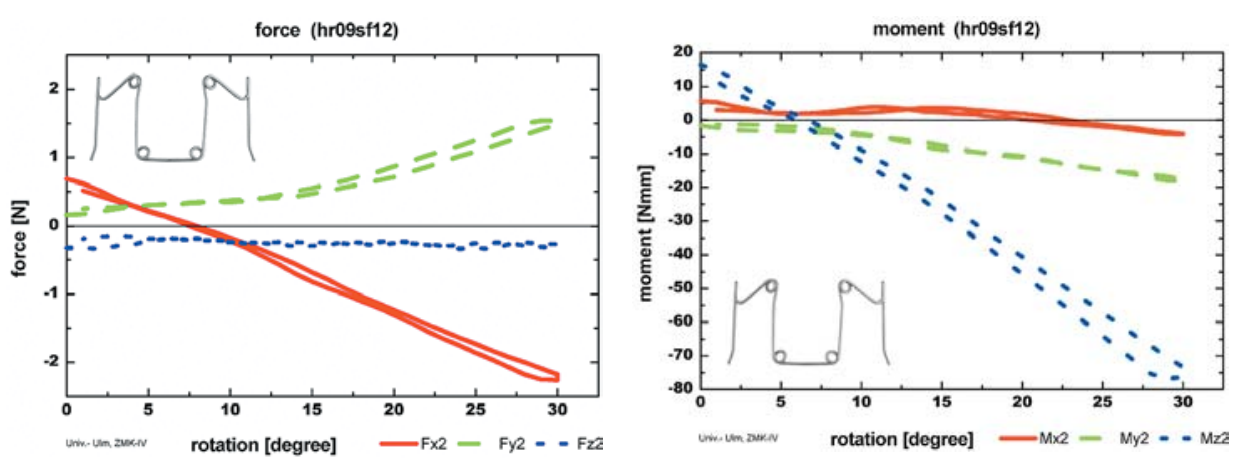

Figures 10a and 10b. Stainless steel quad-helix (Forestadent ${ }^{\circledR}$ ) with rotation. Representation of forces and moments (a: forces, b: moments).

Abbildungen 10a und 10b. Stahl-Quadhelix (Forestadent $\left.{ }^{\circledR}\right)$, Rotation. Darstellung der Kräfte und Momente (a: Kräfte, b: Momente).
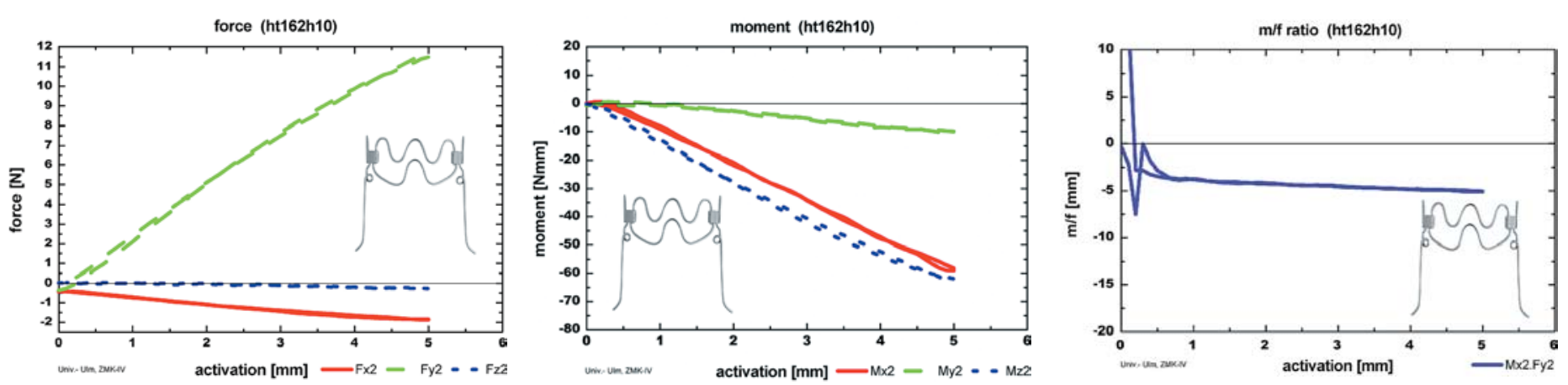

Figures 11a to 11c. Nickel-titanium transpalatal arch $(\mathrm{GAC})$, Arndt memory expander ${ }^{\circledR}$, with expansion. Representation of forces and moments (a: forces, b: moments, c: Mx/Fy).

Abbildungen 11a bis 11c. Nickel-Titan-Palatinalbogen (GAC), Arndt-Memory-Expander ${ }^{\circledR}$, Expansion. Darstellung der Kräfte und Momente (a: Kräfte, b: Momente, c: Mx/Fy).

measurement (Figure 9b). "Residual" forces and moments remained in transversal direction. In this case the measurement started with a preliminary force (Fy) of 0.2 $\mathrm{N}$ (Figure 9a). The moment bent into the arch (Figure 9b) in this case was initially about $-4 \mathrm{Nmm}$ and fell with $5 \mathrm{~mm}$ transversal expansion to $-18 \mathrm{Nmm}$. The resulting $\mathrm{Mx} / \mathrm{Fy}$ ratio (Figure 9c) suggested an almost pure translation from an expansion of $2 \mathrm{~mm}$ or more. The deactivation of the quad-helix below a value of $2 \mathrm{~mm}$ produced a larger $\mathrm{Mx} / \mathrm{Fy}$ ratio, implying buccal molar root movement. In this case too, the moment $\mathrm{Mz}$ declined, implying a distally rotating moment. The stiffness was $0.6 \mathrm{~N} / \mathrm{mm}$.

\section{c) Rotation (Figures 10a and 10b)}

The simulated rotation led to eccentric bends acting on both molars in the reverse directions. Whilst one molar was moved distally, the other was moved mesially with the same force. A simulated $30^{\circ}$ rotation led to eccentric forces of $3 \mathrm{~N}$ in mesiodistal direction (Figure 10a). However, this also led to moments of up to $90 \mathrm{Nmm}$ at $30^{\circ}$ rotation (Figure 10b). To protect teeth from excessive moments, the moments should be below $20 \mathrm{Nmm}$. A rotation of $30^{\circ}$ produced an expanding force $(\mathrm{Fy})$ of $1.5 \mathrm{~N}$. b) Transversale Erweiterung mit Torque (Abbildungen 9a bis 9c)

Es wirkte ein initialer bukkaler Wurzeltorque von $\mathrm{Mx}=-4$ $\mathrm{Nmm}$. Das spannungsfreie Einsetzen war in dieser Messung nicht mehr kontrollierbar (Abbildung 9b). Es blieben „Rest"-Kräfte und -Momente in transversaler Richtung. In diesem Fall begann die Messung bereits mit einer Vorkraft von (Fy) 0,2 N (Abbildung 9a). Das in diesem Fall eingebogene Drehmoment (Abbildung 9b) begann bei ca. $-4 \mathrm{Nmm}$ und fiel bei einer Expansion von $5 \mathrm{~mm}$ auf $-18 \mathrm{Nmm}$. Das sich dabei ergebende $\mathrm{Mx} / \mathrm{Fy}$-Verhältnis (Abbildung 9c) ließ nahezu eine reine Translation ab einer Expansion von $2 \mathrm{~mm}$ erwarten. Die Deaktivierung der Quadhelix unter einem Wert von $2 \mathrm{~mm}$ erzeugte ein größeres $\mathrm{Mx} / \mathrm{Fy}$-Verhältnis und bedeutete eine bukkale Wurzelbewegung der Molaren. Auch in diesem Fall wurde das Moment Mz kleiner und bedeutete ein Moment in Richtung distal rotierend. Die Steifigkeit betrug $0,6 \mathrm{~N} / \mathrm{mm}$.

\section{c) Rotation (Abbildungen 10a und 10b)}

Durch die simulierte Rotation entstanden exzentrische Biegungen, die sich auf die beiden Molaren in umgekehrter Richtung auswirkten. Während ein Molar nach distal bewegt wurde, wurde der andere mit der gleichen Kraft nach mesial bewegt. Eine Rotation von simulierten $30^{\circ}$ führte zu exzentrischen Kräften in mesiodistaler Richtung von 3 N (Abbil- 

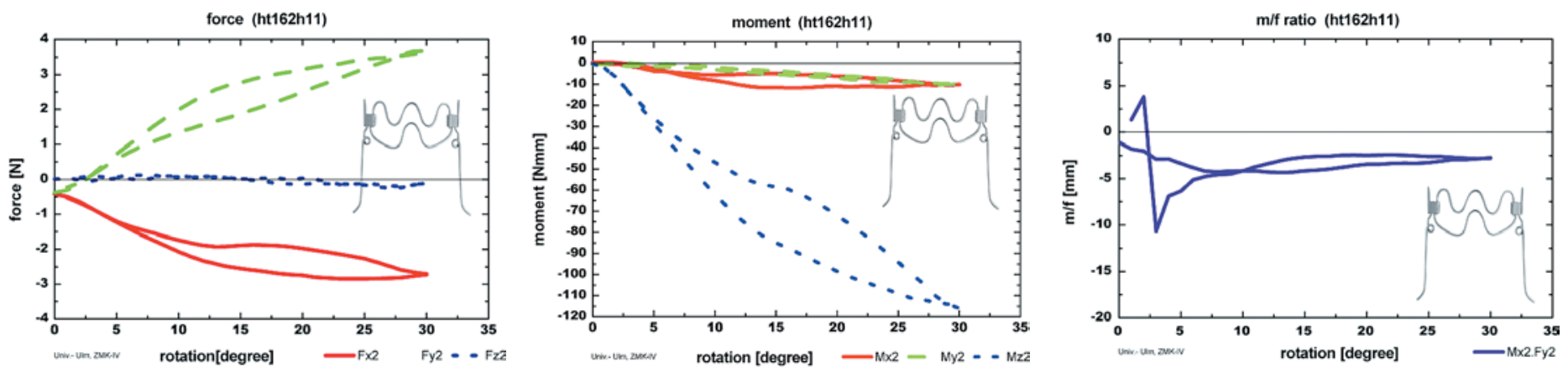

Figures 12a to 12c. Nickel-titanium transpalatal arch $(\mathrm{GAC})$, Arndt memory expander ${ }^{\circledR}$, with rotation. Representation of forces and moments (a: forces, b: moments, c: Mx/Fy).

Abbildungen 12a bis 12c. Nickel-Titan-Palatinalbogen (GAC), Arndt-Memory-Expander ${ }^{\circledR}$, Rotation. Darstellung der Kräfte und Momente (a: Kräfte, b: Momente, c: Mx/Fy).
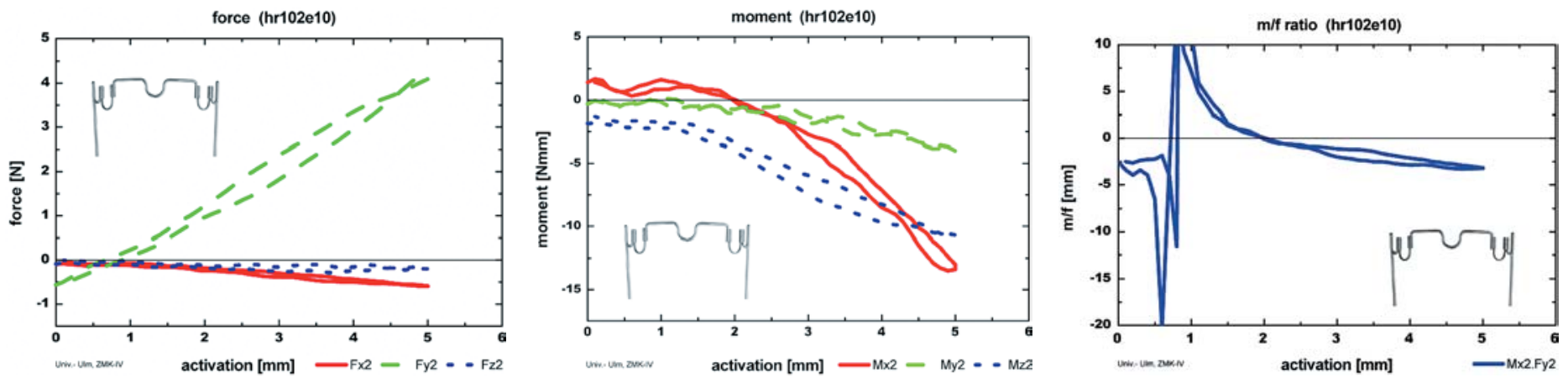

Figures 13a to 13c. Nickel-titanium/stainless steel transpalatal arch (Forestadent ${ }^{\circledR}$ ), Compound palatal $\operatorname{arch}^{\circledR}$, with expansion but no torque. Representation of forces and moments (a: forces, b: moments, c: Mx/Fy).

Abbildungen 13a bis 13c. Nickel-Titan-Stahl-Palatinalbogen (Forestadent ${ }^{\circledR}$ ), Compound-Palatinalbogen ${ }^{\circledR}$, Expansion ohne Torque. Darstellung der Kräfte und Momente (a: Kräfte, b: Momente, c: Mx/Fy).

\section{Arndt Memory Expander ${ }^{\circledR}$}

a) Expansion (Figures 11a to 11c)

A $5 \mathrm{~mm}$ expansion produced a force of $11 \mathrm{~N}$. The measured transversal forces were thus higher than with the quadhelix. There was an almost linear increase in force, with the influence of the nickel-titanium alloy with its pseudoelastic plateau being practically negligible (Figure 11a). The stiffness was $2.2 \mathrm{~N} / \mathrm{mm}$. The buccal root torque was $-35 \mathrm{Nmm}$ up to an expansion of $3 \mathrm{~mm}$ (Figure 11b). Only from $3 \mathrm{~mm}$ activation onwards did the torque increase to $-60 \mathrm{Nmm}$. The Mx/Fy ratio shown by the recording allowed no bodily translation (Figure 11c). Mz showed a distally rotating moment of $-65 \mathrm{Nmm}$ (Figure 11b).

\section{b) Expansion with Added Torque}

As this specific spring did not allow additional torque to be bent in, these measurements could not be performed.

\section{c) Rotation (Figures 12a to 12c)}

With the Arndt memory expander ${ }^{\circledR}$, too, eccentric forces were also to be expected during corrective derotation. With a $30^{\circ}$ rotation the force transmitted in mesiodistal dung 10a). Dadurch entstanden allerdings auch Momente, die bei $30^{\circ}$ bis $\mathrm{zu} 90 \mathrm{Nmm}$ betragen konnten (Abbildung 10b). Um Zähne vor zu großen Momenten zu schützen, sollten die Drehmomente unter $20 \mathrm{Nmm}$ liegen. Die Rotation erzeugte bei $30^{\circ}$ eine expandierende Kraft Fy von 1,5 N.

\section{Arndt-Memory-Expander ${ }^{\circledR}$}

a) Expansion (Abbildungen 11a bis 11c)

Eine Expansion von $5 \mathrm{~mm}$ erzeugte eine Kraft von $11 \mathrm{~N}$. Die gemessenen transversalen Kräfte lagen damit höher verglichen zur Quadhelix. Die Kräfte stiegen nahezu linear an, der Einfluss der Nickel-Titan-Legierung mit dem pseudoelastischen Plateau war praktisch nicht bemerkbar (Abbildung 11a). Die Steifigkeit betrug 2,2 N/mm. Bei der Torqueausübung lag bis zu einer Expansion von $3 \mathrm{~mm}$ der bukkale Wurzeltorque bei $-35 \mathrm{Nmm}$ (Abbildung 11b). Erst ab $3 \mathrm{~mm}$ Aktivierung stieg der Torque auf $-60 \mathrm{Nmm}$ an. Das sich aus dieser Aufzeichnung ergebende Mx/Fy-Verhältnis ließ keine körperliche Translation zu (Abbildung 11c). Mz zeigte ein distal rotierendes Moment von -65 Nmm (Abbildung 11b). 

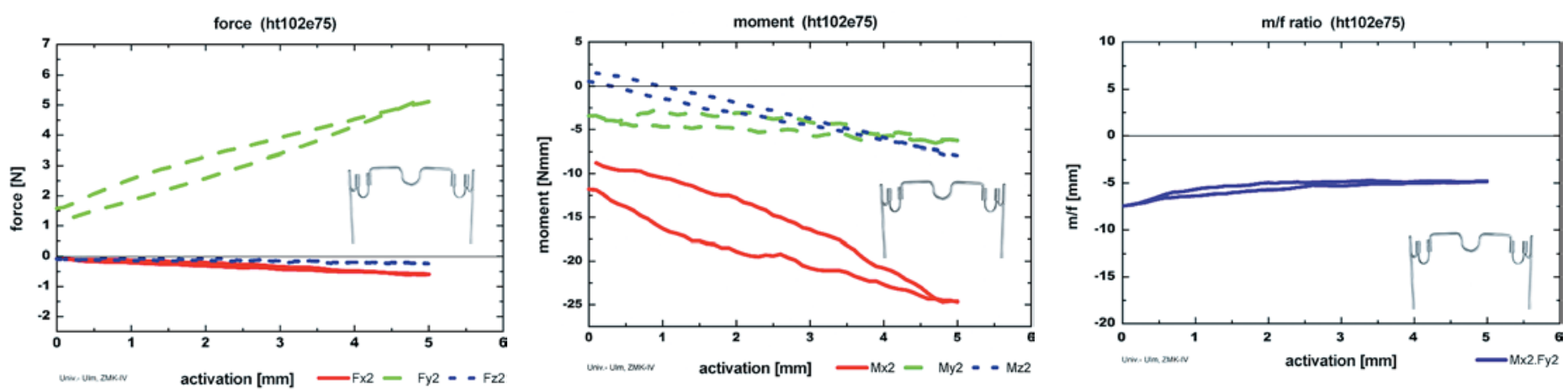

Figures $14 \mathrm{a}$ to $14 \mathrm{c}$. Nickel-titanium/stainless steel transpalatal arch (Forestadent ${ }^{\circledR}$ ), Compound palatal $\operatorname{arch}^{\circledR}$, with expansion with torque. Representation of forces and moments (a: forces, b: moments, c: Mx/Fy).

Abbildungen 14a bis 14c. Nickel-Titan-Stahl-Palatinalbogen (Forestadent ${ }^{\circledR}$ ), Compound-Palatinalbogen ${ }^{\circledR}$, Expansion mit Torque. Darstellung der Kräfte und Momente (a: Kräfte, b: Momente, c: Mx/Fy).
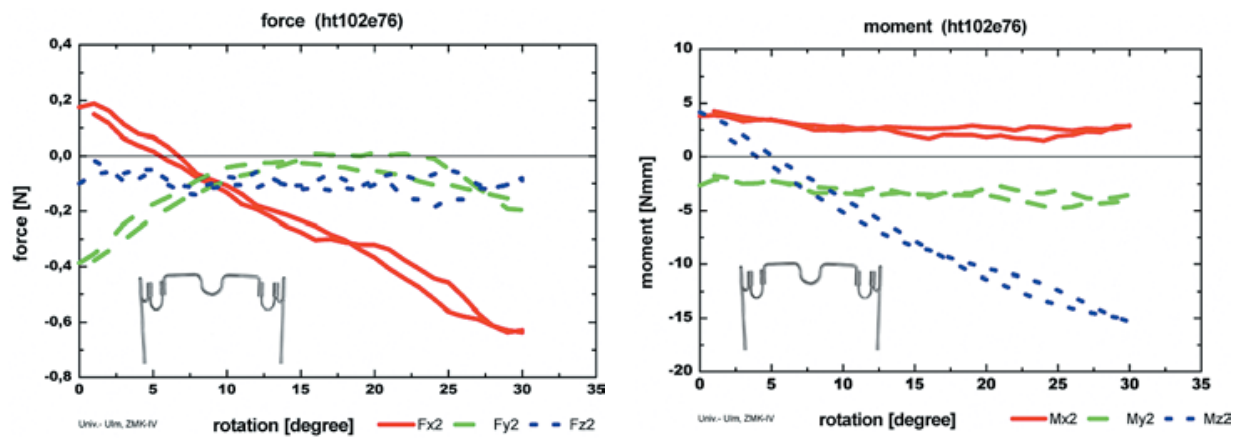

Figures $15 \mathrm{a}$ and $15 \mathrm{~b}$. Nickel-titanium/stainless steel transpalatal arch (Forestadent ${ }^{\circledR}$ ), Compound palatal $\operatorname{arch}^{\circledR}$, with rotation. Representation of forces and moments (a: forces, b: moments).

Abbildungen 15a und 15b. Nickel-Titan-StahlPalatinalbogen (Forestadent ${ }^{\circledR}$ ), Compound-Palatinalbogen ${ }^{\circledR}$, Rotation. Darstellung der Kräfte und Momente (a: Kräfte, b: Momente).

direction was $3 \mathrm{~N}$. This implies a mesializing effect on one side of the jaw and a distalizing effect on the other (Figure 12a). The moments occurring with corrective derotation by $30^{\circ}$ were $-115 \mathrm{Nmm}$ (Figure $12 \mathrm{~b}$ ).

\section{Compound Palatal $\mathrm{Arch}^{\circledR}$}

a) Expansion (Figures 13 a to 13c)

During active expansion by $5 \mathrm{~mm}$, the force reached $4 \mathrm{~N}$ (Figure 13a). However, the resulting moments were more favorable (Figure 13b). With this amount of activation they were only $-15 \mathrm{Nmm}$. The moment Mz suggested distal molar rotation. The stiffness during expansion was 0.8 $\mathrm{N} / \mathrm{mm}$. A bodily movement was not to be expected (Figure 13c).

b) Expansion with Added Torque (Figures 14a to 14c) With the Compound palatal $\operatorname{arch}^{\circledR}$, a $5 \mathrm{~mm}$ activation increased the forces from $5 \mathrm{~N}$ to $5.5 \mathrm{~N}$ (Figure 14a). The stiffness was $1.1 \mathrm{~N} / \mathrm{mm}$. The influence of the superelastic alloy was not detectable. The buccal root torque $(\mathrm{Mx})$ was between -10 and $-25 \mathrm{Nmm}$ over the entire $0-5 \mathrm{~mm}$ activation range (Figure 14b). The moment Mz suggested a distal rotation. Bodily expansion was achieved (Figure 14c).

\section{b) Expansion mit Torque}

Da bei dieser speziellen Feder das nachträgliche Einbiegen von Torque nicht möglich war, konnten auch diese Messungen nicht durchgeführt werden.

c) Rotation (Abbildungen 12a bis 12c)

Bei der Ausrotation war auch bei dem Arndt-Memory-Expander ${ }^{\circledR}$ mit exzentrischen Kräften zu rechnen. Bei einer Rotation von $30^{\circ}$ betrug die übertragene Kraft in mesiodistaler Richtung 3,5 N. Dies bedeutete für die eine Seite eine mesialisierende und für die andere Seite eine distalisierende Wirkung (Abbildung 12a). Bei der Ausrotation entstanden Momente, die bei $30^{\circ}$ Rotation eines Zahnes $-115 \mathrm{Nmm}$ betrugen (Abbildung 12b).

\section{Compound-Palatinalbogen ${ }^{\circledR}$}

a) Expansion ohne Torque (Abbildungen 13a bis 13c) Bei der Expansion erreichte die Kraft $4 \mathrm{~N}$ bei einer Aktivierung von $5 \mathrm{~mm}$ (Abbildung 13a). Günstiger waren jedoch die auftretenden Momente (Abbildung 13b). Sie betrugen bei dieser Aktivierung nur -15 Nmm. Das Moment $\mathrm{Mz}$ ließ eine Distalrotation des Molaren erwarten. Die Steifigkeit bei der Expansion betrug 0,8 N/mm. Eine körperliche Bewegung war nicht $\mathrm{zu}$ erwarten (Abbildung 13c). 
Table 1. Comparison of the values measured for different transpalatal arches following $30^{\circ}$ derotation, $2 \mathrm{~mm}$ expansion and expansion with added torque.

Tabelle 1. Darstellung der gemessenen Werte der verschiedenen Transpalatinalbögen bei $30^{\circ}$ Derotation, $2 \mathrm{~mm}$ Expansion und Expansion und Torque.

\begin{tabular}{lllll}
\hline & Goshgarian & Quad-helix & $\begin{array}{l}\text { Arndt memory } \\
\text { expander }\end{array}$ & $\begin{array}{l}\text { Compound } \\
\text { palatal arch }\end{array}$ \\
\hline $\begin{array}{l}\text { Derotation } \\
\text { Fx }\end{array}$ & $\begin{array}{l}\text { Values too high } \\
\text { to measure }\end{array}$ & $\begin{array}{l}-3 \mathrm{~N} \\
-95 \mathrm{Nmm}\end{array}$ & $-2.8 \mathrm{~N}$ & $-115 \mathrm{Nmm}$ \\
Mz & $4 \mathrm{~N}$ & $1.1 \mathrm{~N}$ & $5 \mathrm{~N}$ & $-19 \mathrm{Nmm}$ \\
Expansion & $-10 \mathrm{Nmm}$ & $-3 \mathrm{Nmm}$ & $-19 \mathrm{Nmm}$ & $1 \mathrm{~N}$ \\
Fy & $-2 \mathrm{~mm}$ & $7 \mathrm{~mm}$ & $4 \mathrm{~mm}$ & $-2.25 \mathrm{Nmm}$ \\
Mx & & & $-2.25 \mathrm{~mm}$ \\
Mx/Fy & $4 \mathrm{~N}$ & $1.1 \mathrm{~N}$ & Additional torque & $1 \mathrm{~N}$ \\
Expansion and & & $-9 \mathrm{Nmm}$ & not possible & $-8 \mathrm{Nmm}$ \\
added torque & $-20 \mathrm{Nmm}$ & $-7.5 \mathrm{~mm}$ & & $-8 \mathrm{~mm}$ \\
Fy & $-6 \mathrm{~mm}$ & &
\end{tabular}

\section{c) Rotation (Figures $15 a$ and $15 b$ )}

With a tooth rotation of up to $30^{\circ}$ the forces were only $1 \mathrm{~N}$ in mesiodistal direction. The eccentric forces resulting in distalization on one side and mesialization on the other were recorded in this case too (Figure 15a). The resulting rotational moments $(\mathrm{Mz})$ reached a maximum of $20 \mathrm{Nmm}$, which can be considered moderate (Figure $15 b)$.

\section{Synopsis}

Table 1 shows a comparison of measurements for the different transpalatal arches with $30^{\circ}$ rotation, $2 \mathrm{~mm}$ expansion, and $2 \mathrm{~mm}$ expansion with buccal root torque. The quad-helix generated a moment of $-95 \mathrm{Nmm}$. The Arndt memory expander ${ }^{\circledR}$ showed the highest moment apart from the Goshgarian arch: $-115 \mathrm{Nmm}$. At $-19 \mathrm{Nmm}$, the moments applied by the Compound palatal $\operatorname{arch}^{\circledR}$ were on the moderate side and within the physiologic limits. With $2 \mathrm{~mm}$ expansion with and without additional buccal root torque, the transversal forces applied to the molar crowns by the Goshgarian arch and the Arndt memory expander ${ }^{\circledR}$ were 4-5 N. The quad-helix and the Compound palatal $\operatorname{arch}^{\circledR}$, however, showed markedly lower forces of $1 \mathrm{~N}$. The additional bending-in of buccal root torque led to bodily tooth movement with the quad-helix and the Compound palatal $\operatorname{arch}^{\circledR}$. This was not achieved with the Goshgarian arch or the Arndt memory expander ${ }^{\circledR}$. The latter arch in fact resulted only in buccal tipping of the crown.

In all cases the clinically applied Compound palatal $\operatorname{arch}^{\circledR}$ met the set requirements, with no handling problems arising.

\section{Discussion}

The investigation of the Goshgarian transpalatal arch failed because of the high forces and moments occurring during the rotation measuring cycles. The limiting values b) Expansion mit Torque (Abbildungen 14a bis 14c) Bei dem Compound-Palatinalbogen ${ }^{\circledR}$ stiegen die Kräfte bei einer Aktivierung von $5 \mathrm{~mm}$ bis auf 5,5 $\mathrm{N}$ an (Abbildung 14a). Die Steifigkeit betrug 1,1 N/mm. Der Einfluss der pseudoelastischen Legierung war nicht erkennbar. Der bukkale Wurzeltorque Mx lag im gesamten Bereich von 0-5 mm Aktivierung zwischen -10 bis $-25 \mathrm{Nmm}$ (Abbildung 14b). Das Drehmoment um Mz ließ auf eine Distalrotation schließen. Die Expansion erfolgte körperlich (Abbildung 14c).

c) Rotation (Abbildungen 15a und 15b)

Bis $\mathrm{zu}$ einer Rotation des Zahnes von $30^{\circ}$ betrugen die Kräfte in mesiodistaler Richtung nur 1 N. Es entstanden wieder die exzentrischen Kräfte, die auf der einen Seite zur Distalisation, auf der anderen zur Mesialisation führten (Abbildung 15a). Die dabei auftretenden ausrotierenden Momente Mz betrugen maximal $20 \mathrm{Nmm}$ und waren somit moderat (Abbildung 15b).

\section{Synopsis}

Tabelle 1 zeigt einen Vergleich der Messergebnisse der verschiedenen Transpalatinalbögen bei $30^{\circ}$ Derotation, $2 \mathrm{~mm}$ Expansion und $2 \mathrm{~mm}$ Expansion mit bukkalem Wurzeltorque. Die Quadhelix erzeugte ein Moment von -95 Nmm. Der Arndt-Memory-Expander ${ }^{\circledR}$ zeigte nach dem Goshgarian das höchste Moment mit $-115 \mathrm{Nmm}$. Eher moderat und im physiologischen Bereich liegend waren die durch den Compound-Palatinalbogen ${ }^{\circledR}$ erzeugten Momente mit -19 Nmm. Bei der Expansion von $2 \mathrm{~mm}$, mit und ohne zusätzlichen bukkalen Wurzeltorque, lagen die erzeugten transversalen Kräfte auf die Molarenkronen bei dem Goshgarian und Arndt-Memory-Expander ${ }^{\circledR}$ bei 4-5 N. Die Quadhelix und der Compound-Palatinalbogen ${ }^{\circledR}$ zeigten dagegen deutlich niedrigere Kräfte von $1 \mathrm{~N}$. Das zusätzliche Einbiegen von bukkalem Wurzeltorque führte bei der Quadhelix und dem Compound-Palatinalbogen ${ }^{\circledR} \mathrm{zu}$ einer körperlichen Zahnbewegung. Dies wurde nicht bei dem 
for moments were exceeded with respect to the sensors. It is not only the high moments generated on the teeth by the Goshgarian arch during corrective rotation that make this appliance unsuitable for active movements. The high sagittal forces occurring in terms of a mesializing molar force in the opposite quadrant also make this appliance problematic. Asymmetric malalignments cannot be corrected with the Goshgarian transpalatal arch. The lack of support in the anterior region or at the anchorage unit means that the reciprocal forces cannot be neutralized. Even for the active treatment of symmetric malalignments, the high forces and moments applied with this appliance cast doubt on the precision of the clinical handling. In addition, minimal differences in activation for corrective bilateral molar derotation may very easily lead to differing sagittal effects in the form of unilateral loss of anchorage.

In transverse activation of the Goshgarian transpalatal arch, the high forces but little clinical leeway also constitute a problem. The present study clearly shows that, for $5 \mathrm{~mm}$ and $8 \mathrm{~mm}$ expansion, the transversally generated forces of $8 \mathrm{~N}$ and $4 \mathrm{~N}$ are too high. On these grounds Proffit [25] too recommends an activation of only $1 \mathrm{~mm}$. With such activation a force of $2 \mathrm{~N}$ is to be expected. Larger activations are to be seen as problematic and should be left to other devices. The magnitude of the force has an effect on root resorption according to studies by Faltin et al. [10,11]. For active appliances the force should therefore be definable and overactivations should be limited. Also, the palatal root torque required during transversal expansion for bodily molar movement can very easily reach high levels.

One problem common to all measurements was their correct reproducibility in the clinical situation. In the simulated situation the palatal arch was not contoured. When the arch is contoured it can be expected to produce lower forces.

According to these investigations, a stainless steel quad-helix can be activated up to a maximum of 4-5 $\mathrm{mm}$. The ideal expansion force of $3 \mathrm{~N}$ determined by Ricketts [26] is then not exceeded. However, the disadvantage is that insufficient torque is transmitted, resulting in buccal tipping of the molars. For a lever arm of $8 \mathrm{~mm}$ and an $\mathrm{Mx} / \mathrm{Fy}$ ratio of $8 \mathrm{~mm}$ a bodily movement (translation) can be assumed. When additional torque is bent into the arch, the activation should be no greater than $4 \mathrm{~mm}$ to ensure that the limits set in the present study are not exceeded. As the results show, the favorable $\mathrm{M} / \mathrm{F}$ ratio of the quad-helix from $2 \mathrm{~mm}$ activation onwards suggests bodily movement. Any lack of torque becomes evident if the quad-helix is not reactivated at the end of the deactivation curve. In this case, the transmitted torque is still 18 $\mathrm{Nmm}$. With respect to bodily tooth movement it has to be kept in mind that the root moves more slowly than the
Goshgarian-Bogen und dem Arndt-Memory-Expander ${ }^{\circledR}$ erreicht. Bei letztgenannten Bögen kam es lediglich zu einer Kronenkippung nach bukkal.

Bei allen klinisch eingesetzten Compound-Palatinalbögen ${ }^{\circledR}$ konnten die gesetzten Ziele erreicht werden. Probleme im Handling traten nicht auf.

\section{Diskussion}

Die Untersuchung der Goshgarian-Palatinalbögen scheiterte an den großen Kräften und Momenten bei den Messzyklen der Rotation. Die Grenzwerte für Momente bei den Sonden wurden überschritten. Nicht nur in Bezug auf die großen Momente, die der Goshgarian-Bogen bei der Ausrotation auf die Zähne erzeugt, ist dieser Bogen für aktive Bewegungen nicht geeignet. Auch die hohen auftretenden sagittalen Kräfte im Sinne einer mesialisierenden Kraft des Molaren im gegenüberliegenden Quadranten macht diese Apparatur problematisch. Die Behandlung von asymmetrischen Zahnfehlstellungen ist mit dem Goshgarian-Bogen nicht möglich. Durch die fehlende Abstützung anterior bzw. an der Verankerungseinheit können die reziproken Kräfte nicht neutralisiert werden. Auch bei symmetrischen aktiven Behandlungsaufgaben ist aufgrund der hohen Kräfte und Momente, die durch diesen Bogen erzeugt werden, ein exaktes klinisches Handling fraglich. Zusätzlich können bei nur minimaler unterschiedlicher Aktivierung bei beidseitiger Derotation der Molaren sehr leicht unterschiedliche sagittale Effekte in Form von einseitigem Verankerungsverlust auftreten.

Bei der transversalen Aktivierung des Goshgarian-Bogens sind auch die hohen Kräfte bei geringem Aktivierungsspielraum das Problem. Diese Studie zeigt deutlich, dass bei 5 und $3 \mathrm{~mm}$ Expansion die transversal erzeugten Kräfte von $8 \mathrm{~N}$ und $4 \mathrm{~N}$ zu groß sind. Aus diesem Grund empfiehlt wohl auch Proffit [25] eine Aktivierung von nur jeweils $1 \mathrm{~mm}$. Bei dieser Aktivierung ist eine Kraft von $2 \mathrm{~N}$ zu erwarten. Größere Aktivierungen müssen als problematisch eingestuft werden und sollten anderen Behelfen überlassen werden. Die Kraftgröße hat nach Untersuchungen von Faltin et al. $[10,11]$ einen Einfluss auf das Resorptionsvorkommen bei Zähnen. Bei aktiven Behandlungselementen sollten daher die Kraftgröße definierbar sein und Überaktivierungen begrenzt werden. Auch der palatinale Wurzeltorque, der bei der transversalen Dehnung für eine körperliche Bewegung des Molaren erforderlich ist, kann bei Anwendung des Goshgarian-Bogens sehr leicht in einen hohen Bereich gelangen.

Allen Messungen gemeinsam ist die Problematik der korrekten Reproduzierbarkeit für den Patienten. Während der Simulation wurden die Palatinalbögen nicht konturiert. Es kann davon ausgegangen werden, dass durch Konturierung der Bögen die produzierten Kräfte kleiner sind.

Eine Quadhelix, aus Stahl gefertigt, kann nach diesen Untersuchungen bis zu einer Aktivierung von maximal 4-5 $\mathrm{mm}$ verwendet werden. In diesem Fall wird die von Ricketts [26] festgelegte expandierende Kraft von $3 \mathrm{~N}$ nicht über- 
crown. This tends to be disregarded with tipping movements in comparison to bodily movement. Caution seems advisable before undertaking further activation. Activation and control appointments need to be adapted accordingly.

In this study, moments of $80 \mathrm{Nmm}$ were measured at $30^{\circ}$ molar rotation with the quad-helix. Sagittal forces of $3 \mathrm{~N}$ are to be expected as a side effect of asymmetric derotation. To keep the applied moment and sagittal side effects on the anchorage at manageable levels and within physiologic limits, a $10-15^{\circ}$ activation is recommended.

The Arndt memory expander ${ }^{\circledR}$ has to be seen as especially problematic. Our results indicate that such an expander cannot be more than $1.5 \mathrm{~mm}$ wider than the current position of the teeth. Since the Arndt memory expander ${ }^{\circledR}$ cannot be adjusted in width or torque, treatment involves replacement with successively wider expanders but still without the correct torque being applied. The Arndt memory expander ${ }^{\circledR}$ seems not to be suited to rotation either, since moments of more than $40 \mathrm{Nmm}$ have to be expected with rotations of $10^{\circ}$ or more.

The behavior of the Compound palatal arch $^{\circledR}$ is similar to that of the stainless steel quad-helix in terms of expansion. Like the quad-helix, it can be adjusted, so that no replacement is necessary. The moments produced are below $20 \mathrm{Nmm}$ for up to $5 \mathrm{~mm}$ activation. As in the case of the quad-helix, the activation should be reduced to 4 $\mathrm{mm}$ if torque is added to the arch. As is the case with many types of transpalatal arch, the generation of transversal forces in particular by the Compound palatal $\operatorname{arch}^{\circledR}$ is due not only to the deflection of the wire but also to torsion in the nickel-titanium sections. The more the arch is bent out of the plane, the greater the torsion will be, so that it is ultimately the final adjustment by the clinician and the anatomic relationships that exert a great influence on the development of the force. Both effects might account for the arch not always functioning in the superelastic part of the force/deflection curve of these nickeltitanium wires.

The special strength of this new treatment approach is in derotation and unilateral distalization, since the moments remain within physiologic limits even with severely rotated molars. Even with greater rotations a moment of $20 \mathrm{Nmm}$ is not exceeded. No preactivation of the Compound palatal $\operatorname{arch}^{\circledR}$ is required on account of the nickeltitanium element. The derotation is automatically activated on insertion of the arch. Reactivation at the recall appointments is accordingly not required during derotation. There is no risk of overactivation or uncontrolled derotation because the moment falls to below $10 \mathrm{Nmm}$ towards the end of derotation from ca. $5^{\circ}$ onwards. One single reactivation is therefore recommended at the end of active derotation. schritten. Der Nachteil liegt jedoch darin, dass zu wenig Torque übertragen wird und es zu einer Kippung der Molaren nach bukkal kommt. Bei einem Hebelarm von $8 \mathrm{~mm}$ bzw. einem Mx/Fy-Verhältnis von $8 \mathrm{~mm}$ kann von einer körperlichen Bewegung (Translation) ausgegangen werden. Dies kann durch zusätzliches Einbiegen von palatinalem Wurzeltorque erreicht werden. Wird zusätzlich der Torque eingebogen, so sollte die Aktivierung bei $4 \mathrm{~mm}$ enden, damit nicht die auch von uns gesetzten Grenzen überschritten werden. Wie die Ergebnisse zeigen, lässt das günstige M/F-Verhältnis bei der Quadhelix ab $2 \mathrm{~mm}$ Aktivierung eine körperliche Translation erwarten. Der eventuell noch fehlende Torque wirkt sich aus, wenn die Quadhelix am Ende ihrer Deaktivierungskurve nicht erneut aktiviert wird.

In diesem Fall beträgt der übertragene Torque immer noch $18 \mathrm{Nmm}$. Bei der körperlichen Bewegung muss auch bedacht werden, dass sich die Wurzel der Zähne langsamer bewegt als die Krone; dies wird bei kippenden Bewegungen im Vergleich zur körperlichen Bewegung zu wenig berücksichtigt. Eine Zurückhaltung bei der erneuten Aktivierung scheint sinnvoll. Aktivierungs- und klinische Kontrolltermine sind darauf abzustimmen.

Für die Derotation der Molaren mit der Quadhelix wurden bei dieser Studie bei $30^{\circ}$ Derotation Momente von 80 Nmm gemessen. Sagittale Kräfte von $3 \mathrm{~N}$ sind als Nebeneffekte bei asymmetrischer Derotation zu erwarten. Um das applizierte Moment und die sagittalen Nebeneffekte auf die Verankerung in überschaubaren, beherrschbaren und physiologischen Grenzen zu halten, ist eine Aktivierung von $10-15^{\circ}$ zu empfehlen.

Der Arndt-Memory-Expander ${ }^{\circledR}$ muss als besonders problematisch angesehen werden. Nach unseren Ergebnissen darf ein solcher Expander maximal 1,5 mm breiter sein als die momentane Position der Zähne. Da der Arndt-MemoryExpander ${ }^{\circledR}$ weder in der Breite noch im Torque nachstellbar ist, kann eine Behandlung nur so durchgeführt werden, indem es jeweils zum Auswechseln dieser Expander kommt, wobei auch in diesem Fall auf den richtigen Torque verzichtet werden muss.

Für die Ausrotation scheint der Arndt-Memory-Expan$\operatorname{der}^{\circledR}$ ebenfalls nicht geeignet zu sein, da bereits ab $10^{\circ}$ mit einem Moment von mehr als $40 \mathrm{Nmm}$ gerechnet werden muss.

Der Compound-Palatinalbogen ${ }^{\circledR}$ verhält sich hinsichtlich der Expansion ähnlich wie die aus Stahl gefertigte Quadhelix. Auch wie diese kann er nachjustiert werden, so dass ein Austausch nicht notwendig ist. Die entstehenden Momente sind bis zu einer Aktivierung von $5 \mathrm{~mm}$ unterhalb von $20 \mathrm{Nmm}$. Bei der gleichzeitigen Eingabe von Torquewerten sollte die Aktivierung wie bei der Quadhelix auf $4 \mathrm{~mm}$ reduziert werden.

Wie bei vielen Konstruktionen der Palatinalbögen ist auch bei dem Compound-Palatinalbogen ${ }^{\circledR}$ insbesondere die Abgabe der transversalen Kräfte nicht nur auf die Verbie- 
A further advantage of the Compound palatal arch ${ }^{\circledR}$ is displayed in the treatment of asymmetric molar positions. The sagittal side effects resulting from derotation can be intercepted without difficulty as the maximum forces are only $1 \mathrm{~N}$. The Compound palatal $\operatorname{arch}^{\circledR}$ is therefore especially suited to the treatment of adult patients. Difficult cases of oligodontia or a reduced dentition can also be successfully treated with this transpalatal arch.

\section{Conclusions}

The Goshgarian palatal arch is less suitable for active molar movement because of the high measured forces and moments. This appliance is therefore not recommended for derotations. The risk of excessively high moments and unphysiologic loading of the teeth is high. For expansion movements, an activation of $1 \mathrm{~mm}$ can be recommended. If transversal translatory movements are required, additional torque must be bent into the arch. The primary indication for the Goshgarian transpalatal arch is the control and anchorage of molars. In this clinical situation the stiffness of the material is an advantage.

The quad-helix offers numerous opportunities for tooth movement. Both symmetric and asymmetric treatment problems can be resolved. If torque is included during transverse expansion, an activation of $2-4 \mathrm{~mm}$ is recommended. The M/F ratio with a residual transversal movement of $2 \mathrm{~mm}$ will be $>8 \mathrm{~mm}$. This means that most torque effect occurs at the end of the transversal movement. Recalls should be scheduled accordingly; a 6- to 8-week interval has proved clinically acceptable. In view of the size of the moments, derotation needs to be carried out in $10-15^{\circ}$ increments, starting from the initial passive state. Adjustments must be bent into the wire at the recall appointments.

The Arndt memory expander ${ }^{\circledR}$ is suitable for transversal expansion, provided buccal tipping of the molar crowns is clinically acceptable. Additional torque application is not possible. One clear disadvantage is in the very high forces and moments measured, which were far in excess of those of the quad-helix or the Compound palatal $\operatorname{arch}^{\circledR}$. Together with the points stated above, the fact that this system cannot be reactivated casts doubt on its potential for clinical application.

The Compound palatal $\operatorname{arch}^{\circledR}$ represents a further development in the field of transpalatal arches. Because of the selected material parameters and the use of a compound element, it makes for improved clinical handling. In addition it offers substantial advantages for specific treatment tasks such as derotation. The moment is limited to $20 \mathrm{Nmm}$ with a $30^{\circ}$ derotation. The sagittal side effects are reduced to a maximum of $1 \mathrm{~N}$. Overactivation and undesirable clinical side effects such as buccal tipping of the molars with asymmetric derotation can thus be avoided. Preactivation and reactivation are not re- gung zurückzuführen, sondern es erfolgt auch eine Torsion in den Nickel-Titan-Stäben. Die Torsion wird um so größer sein, je mehr der Bogen aus der Ebene herausgebogen wird, so dass letztendlich die Formgebung durch den Anwender und die anatomischen Verhältnisse einen großen Einfluss auf die Kraftentwicklung nehmen. Beide Effekte könnten dazu führen, dass nicht immer im pseudoelastischen Teil der Kraft-/Verbiegungskurve dieser Nickel-Titan-Drähte gearbeitet wird.

Die besondere Stärke dieses neuen Behandlungsbehelfes liegt in der Derotation und einseitigen Distalisation, da bei selbst stark rotierten Molaren es nicht zu unphysiologischen Momenten kommt. Selbst bei einer größeren Derotation werden $20 \mathrm{Nmm}$ nicht überschritten. Aufgrund des NiTi-Elementes ist eine Voraktivierung des Compound-Palatinalbogens ${ }^{\circledR}$ nicht erforderlich. Die Derotation läuft automatisch nach Einsetzen des Bogens ab. Nachaktivierungen während der Derotation sind demnach bei den Kontrollsitzungen nicht erforderlich. Eine Überaktivierung und unkontrollierte Derotation muss nicht befürchtet werden, da am Schluss der Derotation ab ca. $5^{\circ}$ das Moment unter $10 \mathrm{Nmm}$ absinkt. Am Schluss der Derotation ist eine einmalige Nachaktivierung daher zu empfehlen.

Ein weiterer Vorteil des Compound-Palatinalbogens ${ }^{\circledR}$ ergibt sich bei der Behandlung von asymmetrischen Molarenpositionen. Die bei der Derotation auftretenden sagittalen Nebeneffekte können problemlos aufgefangen werden. Die Kräfte liegen nur bei maximal $1 \mathrm{~N}$. Insbesondere eignet sich daher der Compound-Palatinalbogen ${ }^{\circledR}$ bei der Behandlung erwachsener Patienten. Auch schwierigere Bewegungen bei Patienten mit Oligodontie oder mit reduziertem Zahnbestand können so aktiv mit einem Transpalatinalbogen erfolgreich durchgeführt werden.

\section{Schlussfolgerungen}

Aufgrund der gemessenen hohen Kräfte und Momente und des kleinen Aktivierungsspielraums ist der GoshgarianBogen für die aktive Molarenbewegung weniger geeignet. Derotationen sollten mit dieser Apparatur möglichst nicht durchgeführt werden. Die Gefahr, in zu große Momente und unphysiologische Belastungen der Zähne zu gelangen, ist hoch. Bei Expansionsbewegungen kann eine Aktivierung von $1 \mathrm{~mm}$ empfohlen werden. Für transversal translatorische Bewegungen ist in jedem Fall Torque einzubiegen. Die Hauptindikation des Goshgarian-Bogens sind die Kontrolle und Verankerung der Molaren. Die Steifigkeit des Materials ist hier klinisch von Vorteil.

Die Quadhelix eröffnet eine Vielzahl von Bewegungsmöglichkeiten. Neben symmetrischen können auch asymmetrische Behandlungsaufgaben gelöst werden. Für die transversale Dehnung kann eine Aktivierung von 2-4 mm empfohlen werden, wenn gleichzeitig Torque eingebogen wird. Das M/F-Verhältnis wird bei einer noch verbleibenden Transversalbewegung von $2 \mathrm{~mm}$ größer $8 \mathrm{~mm}$. Dies bedeu- 
quired for derotation. The desired movement is executed automatically. Transversal movements and torque are comparable with those of the quad-helix in terms of biomechanical data. The clinical handling is the same. The torque application and the $\mathrm{M} / \mathrm{F}$ ratio are slightly more favorable with the Compound palatal $\operatorname{arch}^{\circledR}$.

Overall, the Compound palatal $\operatorname{arch}^{\circledR}$ is a clinically useful new development, inducing outstandingly rapid, efficient tooth movements. Further studies are needed to evaluate the clinical aspects.

\section{References}

1. Andrews L. Six keys to normal occlusion. Am J Orthod 1972;62:296-309.

2. Angle E. Malocclusion of the teeth. Philadelphia: SS White Dental Manufacture Company, 1907.

3. Arndt WV. Nickel titanium palatal expander. J Clin Orthod 1993;27:129-37.

4. Baldini G. Apparative Messung der durch die Torquebiegung am Palatinalbogen entstehenden Drehmomente und der durch die Torqueapplikation entstehenden expansiven Kraft. Inf Orthod Kieferorthop 1981;3:187-98.

5. Baldini G. Wechselwirkung zwischen bukkalem Wurzeltorque und Expansion beim Palatinalbogen nach Goshgarian. Inf Orthod Kieferorthop 1981;3:181-6.

6. Baumann A. Sagittale, vertikale und kippende Einflüsse des Palatinalbogens nach Goshgarian auf die oberen ersten Molaren. Schweiz Monatsschr Zahnmed 1981;91:310-7.

7. Burstone $\mathrm{CJ}$. Precision lingual arches active applications. J Clin Orthod 1994;28:151-8.

8. Casa MA, Faltin RM, Faltin K, et al. Root resorptions in upper first premolars after application of continuous torque moment. Intraindividual study. J Orofac Orthop 2001;62:285-95.

9. Dahlquist A, Gebauer U. Ingervall B. The effect of a transpalatal arch for the correction of first molar rotation. Eur J Orthod 1996;18:257-67.

10. Faltin RM, Arana-Chavez VE, Faltin K, et al. Root resorptions in upper first premolars after application of continuous intrusive forces. J Orofac Orthop 1998;59:208-19.

11. Faltin RM, Faltin K, Sander FG, et al. Ultrastructure of cementum and periodontal ligament after continuous intrusion in humans: a transmission electron microscopy study. Eur $\mathrm{J}$ Orthod 2001;23:35-49.

12. Frank SW, Engel GA. The effects of maxillary quad-helix expansion on cephalometric measurements in growing orthodontic patients. Am J Orthod 1982;81:378-89.

13. Goshgarian RA. Orthodontic palatal arch wires. United States Government Patent Office, 1972.

14. Haberson VA, Myers DR. Midpalatal suture opening during functional cross-bite correction. Am J Orthod 1978;47:310-413.

15. Hempowitz H. Analyse kieferorthopädischer Problemstellungen mit Hilfe der Methode der Finiten Elemente. University of Ulm: Diss rer biol hum, 1999.

16. Hempowitz H, Sander FG, Wichelhaus A, et al. Finite element modelling of orthodontic tooth movement. In: Davidovitch Z, Mah J, eds. Biomechanical mechanisms of tooth eruption, tet, dass der meiste Torqueeffekt am Schluss der Transversalbewegung stattfindet. Entsprechende Kontrollintervalle sind bei den Patienten einzuplanen. Ein 6- bis 8-wöchiges Intervall hat sich klinisch als sinnvoll erwiesen. Die Derotation ist aufgrund der Größe der Momente in $10-15^{\circ}$-Schritten, vom passiven Ausgangszustand aus, durchzuführen und muss bei den einzelnen Kontrollterminen eingebogen werden.

Der Arndt-Memory-Expander ${ }^{\circledR}$ ist bedingt für die transversale Dehnung einsetzbar, wenn klinisch eine Kippung der Kronen nach bukkal erlaubt ist. Eine zusätzliche Torqueapplikation ist nicht möglich. Ein wesentlicher Nachteil ergibt sich durch die sehr hohen Kräfte und Momente, die weit über den gemessenen Werten der Quadhelix und des Compound-Palatinalbogens ${ }^{\circledR}$ lagen. Die fehlende Aktivierungsmöglichkeit macht neben den genannten Punkten den klinischen Einsatz fraglich.

Der Compound-Palatinalbogen ${ }^{\circledR}$ stellt eine Weiterentwicklung im Bereich der Palatinalbögen dar. Aufgrund der gewählten Materialparameter und durch Einsatz eines Compound-Elementes verbessert er das klinische Handling. Zudem zeigt er für bestimmte Behandlungsaufgaben, wie die Derotation, wesentliche Vorteile. Die Momentgröße wird bei einer Derotation von $30^{\circ}$ auf $20 \mathrm{Nmm}$ limitiert. Die sagittalen Nebeneffekte reduzieren sich auf ein Maximum von $1 \mathrm{~N}$. Überaktivierungen und unerwünschte klinische Nebeneffekte wie Bukkalkippung der Seitenzähne bei asymmetrischer Derotation können so vermieden werden. Eine Voraktivierung bei der Derotation und Folgeaktivierungen während der Derotation sind nicht erforderlich. Die gewünschte Bewegung läuft automatisch ab. Transversale Bewegungen und Torque sind bezüglich der biomechanischen Daten vergleichbar zur Quadhelix. Das klinische Handling ist gleich. Die Torqueapplikation und das M/F-Verhältnis ist bei dem Compound-Palatinalbogen ${ }^{\circledR}$ etwas günstiger.

Insgesamt zeigt sich der Compound-Palatinalbogen ${ }^{\circledR}$ als eine klinisch sinnvolle Neuentwicklung. Die eingesetzten Bögen zeigen besonders schnelle und effiziente Zahnbewegungen. Weiterführende klinische Studien müssen dies evaluieren. 
resorption and replacement by implants. Boston, MA: Harvard Society for the Advancement of Orthodontics, 1998: 573-8.

17. Hicks EP. Slow maxillary expansion: A clinical study of the skeletal vs. dental response to low magnitude forces. Am J Orthod 1978;73:121-41.

18. Hotz R. Orthodontie in der täglichen Praxis. Möglichkeiten und Grenzen im Rahmen der Kinderzahnheilkunde. Bern-StuttgartWien: Huber, 1954:483-9.

19. Ingervall B, Honigl KD, Bantleon H-P. Moments and forces delivered by transpalatal arches for symmetrical first molar rotation. Eur J Orthod 1996;18:131-9.

20. Jäger A, Planert J, Modler $\mathrm{H}$, et al. In-vitro-Studie zur Anwendung von Palatinalbögen bei der Kontrolle der Position der oberen Molaren. Fortschr Kieferorthop 1992;53:230-8.

21. Korkhaus G. Moderne orthodontische Therapie. I. Beschreibung der modernen Apparatur. Berlin: Meusser, 1928:91-108.

22. Lee B. Relationships between tooth-movement rate and estimated pressure applied. J Dent Res 1965;44:10-53.

23. McNamara JA Jr, Brudon WL. Orthodontic and orthopedic treatment in the mixed dentition. Ann Arbor, MI: Veedham Press, 1993.

24. MIA-Systems. 109/1980-3. Monrovia, CA: Inter Unitek.

25. Proffit, W. Contemporary Orthodontics. St. Louis-Toronto-London: CV Mosby, 1986.

26. Ricketts RM. Bioprogressive ${ }^{\mathrm{TM}}$ Therapy (German translation: Heideborn M0, Freiburg). Teil II Kapitel 6: Der Aktivierungsmechanismus. Denver, C0: Rocky Mountain Orthodontics, 1980:287-92.

27. Sander C. Die Verbesserung der therapeutischen Wirkung von Palatinalbögen durch die Verwendung von Stahl und superelastischem Material. Ulm: Med Diss, 2001.

28. Sander FG. Eigenschaften superelastischer Drähte und deren Beeinflussung. Inf Orthod Kieferorthop 1990;4:501-14.

29. Sander FG. Biomechanical investigation of the hybrid retraction spring. J Orofac Orthop 2000;61:341-51.

30. Sander FG, Wichelhaus A. Klinische Erfahrungen mit dem TorqueSegment-Bogen (TSB). Fortschr Kieferorthop 1995;56:194-201.
31. Sander FG, Wichelhaus A. Klinische Anwendung der neuen NiTi-SE-Stahl-Aufrichtefeder. Fortschr Kieferorthop 1995;56: 296-308.

32. Sander FG, Wichelhaus A, Schiemann C. Intrusion mechanics according to Burstone with the NiTi-SE-steel uprighting spring. J Orofac Orthop 1996;57:210-23.

33. Staller A. The normal position of the maxillary first molar. Am J Orthod 1954;40:259-71.

34. Strang R. Factors associated with successful orthodontic treatment. Am J Orthod 1952;38:790-800.

35. Wichelhaus A, Sander FG. Biomechanische Prüfung des neuen Torque-Segment-Bogens. Fortschr Kieferorthop 1995;56: 194-201.

36. Wichelhaus A, Sander FG. Entwicklung und Testung einer neuen NiTi-SE-Stahl-Aufrichtefeder. Fortschr Kieferorthop 1995;56: 283-95.

37. Wichelhaus A, Sander FG. Die Anwendung des Compound-Retraktionsbogens. Inf Orthod Kieferorthop 1996;28:407-24.

38. Wichelhaus A. Die Entwicklung und klinische Anwendung superelastischer Bögen und Teilbögen in der Kieferorthopädie. Ulm: Med. Habil-Schrift, 1995.

39. Wilson WL, Wilson RC. Modular 3D lingual appliances. Part 1: Quad Helix. J Clin Orthod 1983;17:761-6.

\section{Address for Correspondence}

Prof. Dr. Andrea Wichelhaus

Clinic of Orthodontics and Pediatric Dentistry

University of Basel

Hebelstr. 3

4056 Basel

Switzerland

Phone (+41/61) 26726-41, Fax -57

e-mail: Andrea.Wichelhaus@unibas.ch 